\title{
Skarga nadzwyczajna w postępowaniu cywilnym - wybrane zagadnienia
}

\section{Wprowadzenie}

Z dniem 3 kwietnia 2018 r. w życie weszła nowa ustawa o Sądzie Najwyższym $^{1}$, która wprowadziła do polskiego porządku prawnego instytucję skargi nadzwyczajnej². Stanowi ona nowy środek zaskarżenia, którego celem jest nadzwyczajna kontrola prawomocnych orzeczeń sądowych w celu zapewnienia ich zgodności z zasadą demokratycznego państwa

${ }^{1}$ Ustawa z dnia 8 XII 2017 r. o Sądzie Najwyższym (Dz.U. 2018, poz. 5 ze zm.), dalej "ustawa o SN".

${ }^{2}$ Artykuły 89-95 ustawy o SN. Regulacje dotyczące skargi nadzwyczajnej przewidziane są ponadto $\mathrm{w}$ art. 1 pkt 1 lit. b, art. 26, art. $59 \S 1$, art. $63 \S 6$ oraz art. 115 ustawy o SN. W uzasadnieniu do przedstawionego przez Prezydenta Rzeczypospolitej Polskiej projektu ustawy o Sądzie Najwyższym (druk sejmowy nr 2003/VIII kadencja), dalej "projekt ustawy o SN", wskazano, że z konstytucyjnych zasad oraz wolności i praw człowieka i obywatela wynika, iż orzeczenia sądowe powinny być sprawiedliwe, wydawane w oparciu o prawidłowo zinterpretowane przepisy prawa, a w końcu odzwierciedlać zebrany i poprawnie oceniony materiał dowodowy, podczas gdy praktyka pokazuje, że w obrocie prawnym pojawiają się prawomocne orzeczenia, którym daleko od ww. standardów (uzasadnienie do projektu ustawy o SN, s. 5). Konstrukcja skargi nadzwyczajnej ma więc uwypuklać konieczność respektowania przez sądy przy orzekaniu zasad konstytucyjnych oraz chronionych konstytucyjnie wolności i praw człowieka i obywatela (uzasadnienie do projektu ustawy o SN, s. 7). Zarazem nie stoi w kolizji z instytucją skargi konstytucyjnej (art. 79 ust. 1 Konstytucji Rzeczypospolitej Polskiej z dnia 2 IV 1997 r. (Dz.U. Nr 78, poz. 483 ze zm.), dalej „Konstytucja RP”), gdyż jak wskazano w uzasadnieniu do projektu ustawy SN, ta nie służy bezpośredniej ochronie konkretnych interesów jednostek, bowiem rozstrzygnięcie TK obejmuje jedynie hierarchiczną kontrolę norm (uzasadnienie do projektu ustawy o SN, s. 7), http://www.sejm.gov.pl/sejm8. nsf/PrzebiegProc.xsp?nr=2003 (dostęp: 27 VI 2018), http://orka.sejm.gov.pl/Druki8ka. nsf/0/5AB89A44A6408C3CC12581D800339FED/\%24File/2003.pdf (dostęp: 27 VI 2018). 
prawnego urzeczywistniającego zasady sprawiedliwości społecznej³ . Przesłanka ta stanowi zresztą podstawowy warunek dopuszczalności jej wniesienia ${ }^{4}$. Wyjątkowy charakter skargi nadzwyczajnej wynika również z faktu, że może ona zostać wniesiona wyłącznie przez ściśle określony w ustawie o SN krąg podmiotów (dalej „podmioty/organy uprawnione" $)^{5}$, tj. przez Prokuratora Generalnego (dalej „PG” ${ }^{6}$, Rzecznika Praw Obywatelskich (dalej „RPO” ${ }^{7}$, a także, w zakresie swojej właściwości, Prezesa Prokuratorii Generalnej Rzeczypospolitej Polskiej (dalej „Prezes PGRP”)8, Rzecznika Praw Dziecka (dalej „RPD”) ${ }^{9}$, Rzecznika Praw Pacjenta (dalej „RPP” ${ }^{10}$, Przewodniczącego Komisji Nadzoru Finansowego (dalej „Przewodniczący KNF”) ${ }^{11}$, Rzecznika Finansowego (dalej „RF”) ${ }^{12}$, Rzecznika Małych i Średnich Przedsiębiorców (dalej

${ }^{3}$ Artykuł 1 pkt 1 lit. b ustawy o SN (aktualna treść tego przepisu wprowadzona została na mocy art. 2 pkt 1 Ustawy z dnia 10 V 2018 r. o zmianie ustawy - Prawo o ustroju sądów powszechnych, ustawy o Sądzie Najwyższym oraz niektórych innych ustaw (Dz.U. 2018, poz. 1045), dalej "nowelizacja ustawy o SN").

${ }^{4}$ Artykuł 89 § 1 in principio ustawy o SN (aktualna treść tego przepisu wprowadzona została na mocy art. 2 pkt 3 lit. a nowelizacji ustawy o SN).

${ }^{5}$ Artykuł $89 \S 2$ ustawy o SN.

${ }^{6}$ Zgodnie z art. 7 zd. 1 Ustawy z dnia 17 XI 1964 r. - Kodeks postępowania cywilnego (Dz.U. Nr 43, poz. 296 ze zm.), dalej „k.p.c.”, rola prokuratora w postępowaniu cywilnym aktualizuje się, jeżeli według jego oceny wymaga tego ochrona praworządności, praw obywateli lub interesu społecznego. Zob. też art. $398^{3} \S 2$ oraz art. $424^{2}$ k.p.c.

7 Zgodnie z art. 1 ust. 2 Ustawy z dnia 15 VII 1987 r. o Rzeczniku Praw Obywatelskich (Dz.U. Nr 21, poz. 123 ze zm.) RPO stoi na straży wolności i praw człowieka i obywatela określonych w Konstytucji RP, oraz w innych aktach normatywnych, w tym również na straży realizacji zasady równego traktowania. Zob. też art. $398^{3} \S 2$ oraz art. $424^{2}$ k.p.c.

${ }^{8}$ Zob. art. 1 ust. 1 Ustawy z dnia 15 XII 2016 r. o Prokuratorii Generalnej Rzeczypospolitej Polskiej (Dz.U. poz. 2261 ze zm.).

${ }^{9}$ Zob. art. 1 ust. 2 Ustawy z dnia 6 I 2000 r. o Rzeczniku Praw Dziecka (Dz.U. Nr 6, poz. 69 ze zm.). Zob. też art. $398^{3} \S 2$ oraz art. $424^{2}$ k.p.c.

${ }^{10}$ Zob. art. 42 ust. 1 Ustawy z dnia 6 XI 2008 r. o prawach pacjenta i Rzeczniku Praw Pacjenta (Dz.U. 2009 Nr 52, poz. 417 ze zm.).

${ }^{11}$ Zgodnie $z$ art. 3 ust. 2 Ustawy z dnia 21 VII 2006 r. o nadzorze nad rynkiem finansowym (Dz.U. Nr 157, poz. 1119 ze zm.) Komisja Nadzoru Finansowego (dalej „KNF”) jest organem właściwym w sprawach nadzoru nad rynkiem finansowym. Natomiast zgodnie z art. 3 ust. 1 Ustawy z dnia 29 VII 2005 r. o nadzorze nad rynkiem kapitałowym (Dz.U. Nr 183, poz. 1537 ze zm.) KNF jest też organem nadzoru nad rynkiem kapitałowym oraz rynkiem instrumentów finansowych będących przedmiotem ubiegania się o dopuszczenie do obrotu na takim rynku, w rozumieniu aktów prawnych wydawanych przez instytucje i organy Unii Europejskiej.

12 Zgodnie z art. 17 ust. 1 in principio Ustawy z dnia 5 VIII 2015 r. o rozpatrywaniu reklamacji przez podmioty rynku finansowego i o Rzeczniku Finansowym (Dz.U. poz. 1348 ze zm.), dalej „ustawa o Rzeczniku”, do zadań RF należy podejmowanie 
"RMiŚP" ${ }^{13}$ oraz Prezesa Urzędu Ochrony Konkurencji i Konsumentów (dalej „Prezes UOKiK") ${ }^{14}$. Prawo takie nie przysługuje natomiast samej stronie postępowania ${ }^{15}$. Ta może jedynie zwrócić się do któregoś z podmiotów uprawnionych, wnioskując o wniesienie skargi nadzwyczajnej w jej sprawie. Skarga nadzwyczajna wniesiona przez organ nieuprawniony podlega odrzuceniu bez wzywania do usunięcia braków ${ }^{16}$.

Celem artykułu jest omówienie podstawowych zagadnień prawnych związanych ze skargą nadzwyczajna, a w szczególności podstaw jej dopuszczalności (przesłanek jej wniesienia) i praktycznych aspektów z tym związanych, oraz zasygnalizowanie pojawiających się wątpliwości interpretacyjnych, biorąc pod uwagę nowy charakter tej instytucji. Opracowanie ogranicza się do analizy wybranych zagadnień związanych ze skargą nadzwyczajną w ramach postępowania cywilnego. Należy bowiem pamiętać, że zasadniczo skarga ta może być wniesiona od prawomocnych orzeczeń sądów powszechnych lub sądów wojskowych kończących postępowanie w sprawie, a więc zarówno w sprawach cywilnych, jak i karnych ${ }^{17}$.

W uzasadnieniu do projektu ustawy o SN stwierdzono, że wprowadzenie instytucji skargi nadzwyczajnej było odpowiedzią na pojawiające się postulaty przywrócenia rozwiązania podobnego do rewizji

działań w zakresie ochrony klientów podmiotów rynku finansowego, których interesy reprezentuje.

${ }^{13}$ Zob. art. 1 ust. 1 Ustawy z dnia 6 III 2018 r. o Rzeczniku Małych i Średnich Przedsiębiorców (Dz.U. poz. 648).

${ }^{14}$ Zgodnie z art. 29 ust. 1 zd. 1 Ustawy z dnia 16 II 2007 r. o ochronie konkurencji i konsumentów (Dz.U. Nr 50, poz. 331 ze zm.), dalej „ustawa u.o.k.i.k.", Prezes UOKiK jest centralnym organem administracji rządowej właściwym w sprawach ochrony konkurencji i konsumentów.

${ }^{15}$ Artykuł 89 § 2 ustawy o SN. Tak samo: R.M. Bełczącki, Badanie dopuszczalności skargi nadzwyczajnej przed Sądem Najwyższym ze względów podmiotowych i przedmiotowych w sprawie cywilnej, pod red. T. Wiśniewskiego, LEX/el., oraz R.M. Bełczącki, Wniesienie skargi nadzwyczajnej od orzeczenia sadu powszechnego w sprawie cywilnej, pod red. T. Wiśniewskiego, LEX/el.

${ }^{16}$ Artykuł $89 \S 2$ ustawy o SN w zw. z art. $398^{6} \S 2$ i 3 k.p.c. w zw. z art. 95 pkt 1 ustawy o SN. Skarga nadzwyczajna wniesiona z naruszeniem art. $90 \S 1$ ustawy o SN podlega natomiast odrzuceniu bez wzywania do usunięcia braków (art. 90 § 1 ustawy o SN w zw. z art. $398^{6} \S 2$ lub $3 \mathrm{w}$ zw. z art. 95 pkt 1 ustawy o SN).

${ }^{17}$ Wynika to wprost z art. 95 ustawy o SN, który nakazuje, aby w zakresie nieuregulowanym przepisami tej ustawy do skargi nadzwyczajnej stosować w sprawach cywilnych przepisy k.p.c. dotyczące skargi kasacyjnej (z wyłączeniem art. $398^{4} \S 2$ oraz art. $398^{9}$ k.p.c.), natomiast w sprawach karnych przepisy Ustawy z dnia 6 VI 1997 r. - Kodeks postępowania karnego (Dz.U. Nr 89, poz. 555 ze zm.), dalej „k.p.k.”, dotyczące kasacji. 
nadzwyczajnej ${ }^{18}$, ale dostosowanego do warunków dzisiejszego ustro$\mathrm{ju}^{19}$. Przepisy ustawy o SN weszły w życie 3 kwietnia 2018 r. ${ }^{20}$, niemniej już po niespełna miesiącu ich obowiązania, tj. w dniu 2 maja 2018 r., do Sejmu RP wniesiony został projekt nowelizacji ustawy o $\mathrm{SN}^{21}$, która uchwalona została niedługo później, a mianowicie 10 maja 2018 r., i weszła w życie 16 czerwca 2018 r. $^{22}$ Zreformowała ona w pewnym zakresie instytucję skargi nadzwyczajnej. Głównym celem zmian było ograniczenie kręgu podmiotów, które mogą wnosić skargę nadzwyczajną od orzeczeń, które się uprawomocniły przed dniem wejścia w życie ustawy o SN (tj. przed dniem 3 kwietnia 2018 r.) ${ }^{23}$. Należy bowiem podkreślić, że pierwotnie (tj. od 3 kwietnia 2018 r. do 16 czerwca 2018 r.) ustawa o SN przewidywała, iż w okresie 3 lat od dnia wejścia jej w życie wszystkie podmioty wskazane w art. 89 § 2 ustawy o SN mogły wnosić skargę nadzwyczajną od prawomocnych orzeczeń kończących postępowanie w sprawach, które uprawomocniły się po dniu 17 października $1997 \mathrm{r} .^{24}$ Tymczasem, dopiero w wyniku nowelizacji ustawy o SN, krąg ten ograniczony został wyłącznie do PG i RPO ${ }^{25}$. Zatem od 16 czerwca 2018 r. do 3 kwietnia 2021 r. tylko PG i RPO mogą wnosić

${ }^{18}$ Na temat rewizji nadzwyczajnej zob. J. Krajewski, Rewizja nadzwyczajna według nowego kodeksu postępowania cywilnego „Palestra” 1965, nr 9/2(86), s. 17-21, http://bazhum. muzhp.pl/media//files/Palestra/Palestra-r1965-t9-n2(86)/Palestra-r1965-t9-n2(86)s17-27/Palestra-r1965-t9-n2(86)-s17-27.pdf (dostęp: 27 VI 2018).

${ }^{19}$ Uzasadnienie do projektu ustawy o SN, s. 5.

${ }^{20}$ Artykuł 136 ustawy o SN.

${ }^{21}$ Poselski projekt ustawy o zmianie ustawy o Sądzie Najwyższym oraz niektórych innych ustaw z dnia 2 V 2018 r. (druk sejmowy nr 2480/VIII kadencja), dalej „projekt nowelizacji ustawy o $\mathrm{SN}^{\prime}$, wraz z uzasadnieniem (dalej „uzasadnienie do projektu nowelizacji ustawy o SN"), http://www.sejm.gov.pl/sejm8.nsf/PrzebiegProc.xsp?nr=2480 (dostęp: 27 VI 2018), http://orka.sejm.gov.pl/Druki8ka.nsf/0/A31EEFEB41F8312BC1258283003703E5/\%24File/2480.pdf (dostęp: 27 VI 2018).

${ }^{22}$ Artykuł 7 nowelizacji ustawy o SN.

${ }^{23}$ Artykuł $115 \S 1$ a ustawy o SN (wprowadzony na mocy art. 2 pkt 5 lit. a nowelizacji ustawy o SN i obowiązujący od 16 czerwca 2018 r.).

${ }^{24}$ Artykuł 115 § 1 ustawy o SN. W takich wypadkach nie stosuje się art. $89 \S 3$ zd. 1 ustawy o SN.

${ }^{25}$ Artykuł $115 \S 1$ a ustawy o SN (wprowadzony na mocy art. 2 pkt 5 lit. a nowelizacji ustawy o SN), zgodnie z którym: „Skarga nadzwyczajna od prawomocnego orzeczenia kończącego postępowanie w sprawie, które uprawomocniło się przed wejściem w życie niniejszej ustawy, może być wniesiona przez Prokuratora Generalnego lub Rzecznika Praw Obywatelskich. Przepisu art. 89 § 2 nie stosuje się". W uzasadnieniu do projektu nowelizacji ustawy o SN wskazano, że zmiana ta ma na celu dodatkowe wzmocnienie nadzwyczajnego charakteru skargi, szczególnie istotnego w odniesieniu do orzeczeń, 
skargi nadzwyczajne od prawomocnych orzeczeń kończących postępowanie w sprawach, które uprawomocniły się po dniu 17 października 1997 r., a przed dniem 3 kwietnia 2018 r. Obecnie natomiast zarówno PG oraz RPO, jak i wszystkie pozostałe podmioty uprawnione wskazane w art. $89 \S 2$ ustawy o SN - z zastrzeżeniem, że podmioty inne niż PG i RPO mogą to czynić wyłącznie w zakresie swojej właściwości - mogą wnosić skargi nadzwyczajne od orzeczeń, które uprawomocniły się po dniu 3 kwietnia 2018 r. (włącznie) ${ }^{26}$. Na mocy nowelizacji ustawy o SN dokonano również zmiany art. $89 \S 1$ ustawy o SN, modyfikując główną, a zarazem obligatoryjną podstawę uprawniającą do jej wniesienia $^{27}$. W myśl zmienionego przepisu skargę nadzwyczajną można więc wnieść - niezależnie od zaistnienia bardziej szczegółowych przesłanek wymienionych w dalszej części art. 89 § 1 ustawy o SN - tylko wtedy, gdy będzie to absolutnie niezbędne z punktu widzenia zasady demokratycznego państwa prawnego urzeczywistniającego zasady sprawiedliwości

które zapadły przed wprowadzeniem tego środka do polskiego systemu prawnego (uzasadnienie do projektu nowelizacji ustawy o SN, s. 6).

${ }^{26}$ Artykuł $89 \S 2$ w zw. z art. 136 ustawy o SN. Artykuł $115 \S 1$ i 1a ustawy o SN - argumentacja a contrario. Tak samo R.M. Bełczącki, Badanie dopuszczalności skargi nadzwyczajnej przed Sądem Najwyższym ze względu na zachowanie terminu do jej wniesienia w sprawie cywilnej, pod red. T. Wiśniewskiego, LEX/el.

${ }^{27}$ Artykuł 2 pkt 3 lit. a nowelizacji ustawy o SN. Z pierwotnej treści art. $89 \S 1$ in principio ustawy o SN wynikało bowiem, że główną podstawą wniesienia skargi nadzwyczajnej była konieczność zapewnienia praworządności i sprawiedliwości społecznej. W uzasadnieniu do projektu nowelizacji ustawy o SN wskazano natomiast, że „Sformułowanie zawarte obecnie w art. $89 \S 1$ ustawy jest klauzulą generalną odmienną od istniejącej od dawna w polskim porządku prawnym zasady z art. 2 Konstytucji (choć w pewnym zakresie do niej podobną), a jego wykładnia wymagałaby dopiero ugruntowania w drodze orzecznictwa sądów. Mogło to prowadzić do stanu swoistej niepewności prawnej co do zakresu znaczeniowego tej przesłanki, co w konsekwencji każdorazowo utrudniałoby dokonywanie jej subsumpcji w odniesieniu do skonkretyzowanych stanów faktycznych. Zastąienie dotychczasowego sformułowania odwołaniem expressis verbis do normy rangi konstytucyjnej, stanowiącej naczelną zasadę ustrojową państwa, będącej od kilkudziesięciu lat przedmiotem rozbudowanego orzecznictwa sądów i Trybunału Konstytucyjnego, pozwoli zapobiec powstaniu potencjalnego stanu niepewności prawa oraz ugruntuje nadzwyczajny charakter środka zaskarżenia przewidzianego w art. 89 nowelizowanej ustawy" (uzasadnienie do projektu nowelizacji ustawy o SN, s. 5). Uległa ona zmianie w ten sposób, że $\mathrm{w}$ miejsce tej przesłanki wprowadzono wstępny warunek realizujący expressis verbis naczelną zasadę ustroju Rzeczypospolitej Polskiej wywodzącą się z art. 2 Konstytucji RP (art. $89 \S 1$ in principio ustawy o SN; zob. też uzasadnienie do projektu nowelizacji ustawy o SN, s. 5). 
społecznej $^{28}$. W takim kształcie instytucja skargi nadzwyczajnej obowiązuje od dnia 16 czerwca 2018 r. ${ }^{29}$

\section{Cechy i cele skargi nadzwyczajnej}

Zasadne wydaje się przyjęcie, że celem skargi nadzwyczajnej, podobnie jak skargi kasacyjnej, jest - przynajmniej w pewnym zakresie - realizacja interesu publicznego, choć pojawiają się w tym zakresie istotne różnice. Za pierwiastkiem publicznoprawnym przemawia fakt, że skarga nadzwyczajna może być wniesiona wyłącznie przez ściśle określony krąg podmiotów ${ }^{30}$. Inaczej zatem niż w przypadku skargi kasacyjnej, strona nie ma uprawnienia do jej samodzielnego wniesienia. Ma ona oczywiście prawo zwrócenia się do organów uprawnionych z wnioskiem o wniesienie skargi nadzwyczajnej w jej sprawie, natomiast nie powinno budzić wątpliwości, że podmioty te nie są takim wnioskiem związane. Możliwość wniesienia skargi nadzwyczajnej jest zatem

${ }^{28}$ Artykuł 89 § 1 in principio ustawy o SN. Zob. też uzasadnienie do projektu nowelizacji ustawy o SN, s. 5. Intencją autorów projektu nowelizacji ustawy o SN było podkreślenie (umocnienie) wyjątkowego i nadzwyczajnego charakteru skargi (uzasadnienie do projektu nowelizacji ustawy o SN, s. 6), tak aby nie mogła być ona nadużywana ponad rzeczywistą intencję ustawodawcy (uzasadnienie do projektu nowelizacji ustawy o SN, s. 5). Wydaje się jednak, że w rzeczywistości nowelizacja ustawy o SN w omawianym zakresie nie realizuje tak zarysowanego celu. Przeciwnie, wprowadzona zmiana może być rozpatrywana jako rozszerzająca zakres głównej podstawy wniesienia skargi nadzwyczajnej. Wszak praworządność i sprawiedliwość społeczna wywodzone są właśnie z art. 2 Konstytucji RP, który to przepis wydaje się obejmować szerszy katalog wartości, praw, wolności i zasad. W doktrynie wskazuje się, że art. 2 Konstytucji RP „wyraża trzy odrębne zasady konstytucyjne: państwa demokratycznego, prawnego i sprawiedliwości społecznej" (P. Tuleja, Komentarz do art. 2, w: Konstytucja RP Komentarz do art. 1-86, t. 1, pod red. M. Safjana, L. Boska, Warszawa 2016). Zasada praworządności stanowi zatem odrębną zasadę konstytucyjną wyrażoną w art. 7 Konstytucji RP, niemniej równocześnie stanowi emanację (rozwinięcie) zasady demokratycznego państwa prawnego określonej w art. 2 Konstytucji RP. Istotnie, tak sformułowana podstawa nie budzi wątpliwości w przedmiocie możliwości odwoływania się do ugruntowanego orzecznictwa Trybunału Konstytucyjnego (dalej „TK"), ukształtowanego na tle wykładni i stosowania art. 2 Konstytucji RP (uzasadnienie do projektu nowelizacji ustawy o SN, s. 5; zob. również przypis poprzedni). Niemniej wydaje się, że pierwotna treść art. $89 \S 1$ in principio ustawy o SN takich wątpliwości także nie budziła.

${ }^{29}$ Artykuł 7 nowelizacji ustawy o SN.

${ }^{30}$ Jakkolwiek działania tych podmiotów niejednokrotnie podejmowane są w indywidualnych sprawach obywateli, równocześnie zmierzają one do zapewnienia ochrony interesu społecznego, obywatelskiego czy też publicznego. 
uprawnieniem, a nie obowiązkiem podmiotów wymienionych w art. 89 $\S 2$ ustawy o $\mathrm{SN}^{31}$. Oznacza to, że ustawodawca pozostawił organom uprawnionym szeroką swobodę w podjęciu decyzji, czy w danej sprawie wniesienie skargi nadzwyczajnej uznać za zasadne ${ }^{32}$. Druga istotna różnica $w$ porównaniu ze skargą kasacyjną związana jest $z$ instytucją tzw. przedsądu. Na podstawie art. $398^{9} \S 1$ w zw. z art. $398^{4} \S 2$ k.p.c. skarga kasacyjna może zostać przyjęta do rozpoznania tylko w czterech enumeratywnie wskazanych wypadkach ${ }^{33}$. SN wskazał, że przedsąd jest elementem zmierzającym do radykalnego przyspieszenia załatwienia spraw poprzez eliminację skarg kasacyjnych oczywiście bezzasadnych lub niedających asumptu do ujednolicenia praktyki sądowej lub rozwoju prawa i jurysprudencji - urzeczywistnia więc zasadę de minimis non curat praetor ${ }^{34}$. Tymczasem, zgodnie $\mathrm{z}$ art. 95 pkt 1 ustawy o SN, $\mathrm{w}$ zakresie nieuregulowanym przepisami tej ustawy, do skargi nadzwyczajnej, w tym do postępowania w sprawie tej skargi, stosuje się w zakresie spraw cywilnych przepisy k.p.c. dotyczące skargi kasacyjnej, z wyłączeniem jednak art. $398^{4} \S 2$ oraz art. $398^{9}$ k.p.c. Ustawa o SN wyłącza więc explicite instytucję przedsądu w odniesieniu do skargi

${ }^{31} \mathrm{~W}$ tym zakresie skargę nadzwyczajną można porównać do instytucji istotnego poglądu wydawanego przez organizacje pozarządowe i inne podmioty (art. 63-63 k.p.c.), Prezesa UOKiK (art. 31d ustawy u.o.k.i.k.) czy RF (art. 28 ustawy o Rzeczniku w zw. z art. 63 k.p.c.). Ugruntowane zarówno w orzecznictwie (wyrok SN z 11 XII 1980 r., sygn. I PR 62/80, Legalis nr 22393), jak i w doktrynie jest stanowisko, że przedłożenie sądowi istotnego poglądu jest prawem, nie zaś obowiązkiem podmiotów uprawnionych (B. Wyżykowski, Istotny pogląd Rzecznika Finansowego jako instrument ochrony klientów podmiotów rynku finansowego, "Studia Prawa Publicznego” 2018, nr 1(21), s. 134 oraz przypisy 42-44). Brak podstaw, by przyjmować odmienne stanowisko w odniesieniu do skargi nadzwyczajnej, z tym zastrzeżeniem, że uprawnienie podmiotów wskazanych w art. $89 \S 2$ ustawy o SN ograniczone jest przesłankami, o których mowa w art. $89 \S 1$ ustawy o SN. Wydaje się, że nie budzi również wątpliwości, iż wniesienie przez PG, RPO czy RPD skargi kasacyjnej (art. $398^{1} \S 1$ w zw. z art. $398^{3} \S 2$ k.p.c.) oraz skargi o stwierdzenie niezgodności z prawem prawomocnego orzeczenia (art. $424^{2}$ k.p.c.) jest uprawnieniem, nie zaś obowiązkiem tych podmiotów.

32 Odmowa wniesienia skargi nadzwyczajnej nie podlega kontroli sądowej (R.M. Bełczącki, Wniesienie skargi nadzwyczajnej...).

${ }^{33}$ Pomijając przypadki oczywistej zasadności skargi kasacyjnej lub nieważności postępowania, przyjęcie jej do rozpoznania nastąpi tylko i wyłącznie w przypadku, gdy w sprawie występuje istotne zagadnienie prawne lub istnieje potrzeba wykładni przepisów prawnych budzących poważne wątpliwości lub wywołujących rozbieżności w orzecznictwie sądów (przedsąd). Skarga kasacyjna niespełniająca wymagań, o których mowa w art. $398^{1} \S 1$ pkt 2 k.p.c., podlega odrzuceniu (art. $398^{6} \S 2$ i 3 k.p.c.).

${ }^{34}$ Uchwała Składu Siedmiu Sędziów SN z 17 I 2001 r., sygn. III CZP 49/00, Legalis nr 48910. 
nadzwyczajnej. Nie oznacza to jednak, że skargę nadzwyczajną można uznać za "powszechny” środek zaskarżenia. Pomijając ograniczony krąg podmiotów legitymowanych do jej wniesienia, przemawia za tym również sama nazwa omawianego środka, determinująca jego nadzwyczajny charakter. Wniesienie skargi nadzwyczajnej musi mieć zatem głębokie uzasadnienie merytoryczne i systemowe, choć na pierwszy plan wysuwa się konieczność ochrony indywidualnych praw lub interesów poszkodowanej strony.

\section{Podstawy wniesienia skargi nadzwyczajnej}

\subsection{Klasyfikacja przesłanek skargi nadzwyczajnej}

Zgodnie z art. $89 \S 1$ ustawy o SN skarga nadzwyczajna może zostać wniesiona, jeżeli jest to konieczne dla zapewnienia zgodności z zasadą demokratycznego państwa prawnego urzeczywistniającego zasady sprawiedliwości społecznej, o ile: (1) orzeczenie narusza zasady lub wolności i prawa człowieka i obywatela określone w Konstytucji lub (2) orzeczenie w sposób rażący narusza prawo przez błędną jego wykładnię lub niewłaściwe zastosowanie, lub (3) zachodzi oczywista sprzeczność istotnych ustaleń sądu z treścią zebranego w sprawie materiału dowodowego. Pojawia się pytanie o wzajemną relację wskazanych przesłanek merytorycznych. Z uzasadnienia do projektu nowelizacji ustawy o SN wynika, że konieczne jest jednoczesne spełnienie warunku głównego (podstawy wskazanej $\mathrm{w}$ art. $89 \S 1$ in principio ustawy o SN) oraz zaistnienie którejś z sytuacji z art. $89 \S 1$ pkt $1-3$ ustawy o $\mathrm{SN}^{35}$. W takim ujęciu przesłanka główna ma charakter obligatoryjny, co oznacza,

${ }^{35}$ Uzasadnienie do projektu nowelizacji ustawy o SN, s. 5 i 6 . Zob. też przypis 48 w niniejszym tekście. W tym kontekście chybiony wydaje się wyrażony w doktrynie pogląd, zgodnie z którym stwierdzenie przez SN jednej z podstaw wskazanych w art. 89 $\S 1$ pkt 2 lub pkt 3 ustawy o SN aktualizuje kontrolę SN z punktu widzenia naruszenia zasad lub wolności i praw człowieka określonych w Konstytucji RP na podstawie art. 89 $\S 1$ pkt 1 ustawy o SN, co sugerowałoby, że przesłanka z tego przepisu ma charakter obligatoryjny (R.M. Bełczącki, Rozpoznanie skargi nadzwyczajnej przez Sąd Najwyższy w sprawie cywilnej, pod red. T. Wiśniewskiego, LEX/el.). W konsekwencji za chybiony należałoby również uznać pogląd, że "Naruszenie zasad lub wolności i praw człowieka i obywatela określonych w Konstytucji musi towarzyszyć naruszeniom określonym w art. 89 § 1 pkt 2 lub pkt 3 ustawy o SN" (R.M. Bełczącki, Badanie dopuszczalności skargi nadzwyczajnej przed Sąem Najwyższym ze względu na wymagania konstrukcyjne skargi w sprawie cywilnej, pod red. T. Wiśniewskiego, LEX/el.). 
że w każdym wypadku musi stanowić podstawę wnoszonej skargi nadzwyczajnej. Natomiast przesłanki, o których mowa w art. $89 \S 1$ pkt 1-3 ustawy o SN, mają charakter fakultatywny w tym sensie, że nie muszą być spełnione kumulatywnie. Wystarczy przywołanie przez organ uprawniony - obok przesłanki głównej - jednej z nich jako podstawy skargi nadzwyczajnej. Jednocześnie pojawia się trudność z ustaleniem różnic między przesłanką główną wskazaną w art. 89 § 1 in principio ustawy o SN a przesłanka, o której mowa w art. $89 \S 1$ pkt 1 ustawy o SN - obie stanowią bowiem zbliżone i bardzo szerokie klauzule generalne, co będzie przedmiotem dalszych rozważań. Ponadto koniecznym warunkiem umożliwiającym wniesienie skargi nadzwyczajnej jest istnienie prawomocnego orzeczenia sądu powszechnego lub sądu wojskowego kończącego postępowanie w sprawie, które nie może być uchylone lub zmienione w trybie innych nadzwyczajnych środków zaskarżenia.

\subsection{Konieczność zapewnienia zgodności z zasadą demokratycznego państwa prawnego urzeczywistniającego zasady sprawiedliwości społecznej}

Główną podstawą wniesienia skargi nadzwyczajnej jest konieczność zapewnienia zgodności z zasadą demokratycznego państwa prawnego urzeczywistniającego zasady sprawiedliwości społecznej (art. 89 \& 1 in principio ustawy o $\mathrm{SN}^{36}$ ). Przepis ten stanowi klauzulę porządku publicznego i odwołuje się - na co zresztą wskazano w uzasadnieniu do projektu nowelizacji ustawy o $\mathrm{SN}^{37}$ - wprost do art. 2 Konstytucji RP. Katalog wartości, zasad, praw, wolności, a także i obowiązków wywodzony $z$ tego przepisu przez $\mathrm{SN}$, sądy powszechne i administracyjne, a w szczególności przez TK, jest niezwykle obszerny i jego szczegółowa analiza znacząco wykraczałaby poza ramy niniejszego opracowania. W tym miejscu warto więc zaznaczyć, że w doktrynie wskazuje się, iż art. 2 Konstytucji RP wyraża trzy odrębne zasady konstytucyjne: państwa demokratycznego, prawnego i sprawiedliwości społecznej, które mają charakter komplementarny i są ze sobą ściśle powiązane

${ }^{36}$ Do skargi nadzwyczajnej nie znajdzie zastosowania art. $398^{3}$ k.p.c., gdyż podstawy skargi nadzwyczajnej uregulowane zostały wyczerpująco w art. 89 § 1 ustawy o SN.

${ }^{37}$ Uzasadnienie do projektu nowelizacji ustawy o SN, s. 5. Zob. też przypisy nr 27 i $28 \mathrm{w}$ niniejszym tekście. 
funkcjonalnie oraz treściowo ${ }^{38}$. Jako elementy klauzuli państwa prawnego wskazuje się np. zasadę proporcjonalności w ograniczaniu praw, prawo do sądu, prawo do odszkodowania za niezgodne z prawem działanie władz publicznych, zasadę legalizmu czy zasadę dwuinstancyjności postępowania sądowego ${ }^{39}$. Co się tyczy zasady sprawiedliwości społecznej, z orzecznictwa TK wynika, że również na jej treść składa się wiele zagadnień ${ }^{40}$ i nie da się jej sprowadzić do prostej normatywnej formuły - stanowi ona cel, który ma urzeczywistniać demokratyczne państwo prawne ${ }^{41}$. Z art. 2 Konstytucji RP wywodzi się także zasadę sprawiedliwości (rzetelności) proceduralnej ${ }^{42}$. TK stwierdził, że zasada ta należy do istoty konstytucyjnego prawa do sądu, ponieważ w przeciwnym razie (bez zachowania standardu rzetelności postępowania) byłoby ono prawem fasadowym ${ }^{43}$. Szczególną gwarancją przestrzegania

${ }^{38}$ P. Tuleja, Komentarz do art. 2. Autor wskazuje również, że ponieważ zasada państwa prawnego odegrała szczególną rolę w rozwoju polskiego konstytucjonalizmu po 1989 r., to właśnie ona jest podstawową zasadą ustrojową i wyraża wiele zasad wprost w Konstytucji RP niewymienionych oraz wpływa na sposób wykładni wielu jej przepisów.

${ }^{39}$ Ibidem. Autor wskazuje również, że "Dla normatywnego kształtu klauzuli państwa prawnego najważniejsza jest idea ograniczenia arbitralnej władzy państwa nad osobą oraz określenia relacji osoba - państwo. W skład klauzuli państwa prawnego wchodzą więc nie tylko wolności i prawa człowieka, ale również zasady określające sposób działania organów władzy publicznej".

${ }^{40}$ Między innymi: zasada równości wobec prawa, tworzenie warunków zdrowego i stabilnego rozwoju gospodarczego, równowaga budżetowa, prawo obywateli i ich wybranych przedstawicieli do ustalania kierunków i priorytetów polityki społecznej oraz gospodarczej na drodze procedur demokratycznych (wyrok TK z 25 II 1997 r., sygn. K 21/95, Legalis nr 10349; wyrok TK z 19 II 2001 r., sygn. SK 14/00, Legalis nr 49470; wyrok TK z 7 IV 2009 r., sygn. P 7/08, Legalis nr 126225; wyrok TK z 16 XI 2010 r., sygn. $\mathrm{K}$ 2/10, Legalis nr 262471).

${ }^{41}$ P. Tuleja, Komentarz do art. 2. Zob. też wyrok TK z 12 IV 2000 r., sygn. K 8/98, Legalis nr 47037; wyrok TK z 17 VI 2003 r., sygn. P 24/02, Legalis nr 57073.

${ }^{42}$ P. Tuleja, Komentarz do art. 2. Autor wskazuje, że na zasadę sprawiedliwości proceduralnej składają się co najmniej następujące wymagania: możności bycia wysłuchanym, ujawniania w sposób czytelny motywów rozstrzygnięcia, co ma zapobiegać jego dowolności i arbitralności, oraz zapewnienia uczestnikowi postępowania przewidywalności przebiegu postępowania.

${ }^{43}$ Zob. wyrok TK z 16 I 2006 r., sygn. SK 30/05, Legalis nr 72310; wyrok TK z 30 V 2007 r., sygn. SK 68/06, Legalis nr 82512; wyrok TK z 20 V 2008 r., sygn. P 18/07, Legalis nr 98265; wyrok TK z 12 VII 2011 r., sygn. SK 49/08, Legalis nr 344785. Prawo do skutecznego środka prawnego i dostępu do bezstronnego sądu wynika również z art. 47 Karty praw podstawowych UE (OJ C 326, 26 X 2012, s. 391-407), dalej „Karta praw podstawowych UE". Zob. też wyrok Trybunału Sprawiedliwości Unii Europejskiej z 21 XII 2016 r. w sprawie C-119/15 Biuro podróży "Partner" sp. z o.o. sp.k. w Dąbrowie Górniczej przeciwko Prezesowi Urzędu Ochrony Konkurencji i Konsumentów (ECLI:EU:C:2016:987), pkt 40-47, 
zasady sprawiedliwości proceduralnej jest m.in. prawo strony do bycia wysłuchaną ${ }^{44}$. Należy podkreślić, że prawo do sądu wyartykułowane zostało wprost w art. 45 Konstytucji RP ${ }^{45}$. Przyjmuje się, że składają się na nie trzy podstawowe elementy: prawo dostępu do sądu (tj. prawo uruchomienia postępowania), prawo do odpowiedniego ukształtowania postępowania sądowego (zgodnie z wymaganiami sprawiedliwości i jawności) oraz prawo do wyroku sądowego (tj. prawo do uzyskania wiążącego rozstrzygnięcia danej sprawy przez sąd $)^{46}$.

Taki sposób ujęcia głównej podstawy uprawniającej do wniesienia skargi nadzwyczajnej w praktyce powoduje wiele trudności. Po pierwsze, wbrew - jak się wydaje - intencjom ustawodawcy, powoduje, że w istocie

oraz opinię Rzecznika Generalnego Henrika Saugmandsgaarda ØE przedstawioną w dniu 2 VI 2016 r., sprawa C-119/15 Biuro podróży "Partner" Sp. z o.o., Sp. komandytowa w Dąbrowie Górniczej przeciwko Prezesowi Urzędu Ochrony Konkurencji i Konsumentów (ECLI:EU:C:2016:387), pkt 58-71.

${ }^{44}$ Zob. wyrok z 16 I 2006 r., sygn. SK 30/05, Legalis nr 72310; wyrok TK z 20 XII 2007 r., sygn. P 39/06, Legalis nr 89922; wyrok TK z 26 II 2008 r., sygn. SK 89/06, Legalis nr 93712; wyrok TK z 21 VII 2009 r., sygn. K 7/09, Legalis nr 160632; wyrok TK z 20 X 2010 r., sygn. P 37/09, Legalis nr 254425.

${ }^{45}$ Zgodnie z art. 45 ust. 1 Konstytucji RP „Każdy ma prawo do sprawiedliwego i jawnego rozpatrzenia sprawy bez nieuzasadnionej zwłoki przez właściwy, niezależny, bezstronny i niezawisły sąd". Natomiast zgodnie z art. 175 ust. 1 Konstytucji RP „Wymiar sprawiedliwości w Rzeczypospolitej Polskiej sprawują Sąd Najwyższy, sądy powszechne, sądy administracyjne oraz sądy wojskowe". W kontekście art. 45 Konstytucji RP w doktrynie wskazano, że "Trybunał Konstytucyjny uznał równocześnie zbędność powoływania jako podstawy kontroli zasady demokratycznego państwa prawnego, gdy obowiązująca Konstytucja, w odróżnieniu od poprzedniczki, zawiera konkretną normę statuującą prawo traktowane dotychczas jako element zasady demokratycznego państwa prawnego i z niej wywodzone (np. prawo do sądu)" (B. Banaszak, Komentarz do art. 7, w: idem, Konstytucja Rzeczypospolitej Polskiej. Komentarz, Warszawa 2012). Wydaje się jednak, że jakkolwiek prawo do sądu wprost wyartykułowane zostało w art. 45 Konstytucji RP, równocześnie wywodzone jest z zasady demokratycznego państwa prawnego i zasady sprawiedliwości społecznej. Stąd ewentualne naruszenie prawa jednostki do sądu (sensu largo) powinno być oceniane jako spełniające główną podstawę wniesienia skargi nadzwyczajnej, o której mowa w art. 89 § 1 in principio ustawy o SN.

${ }^{46}$ B. Banaszak, op. cit. Zob. też wyrok TK z 25 I 1995 r., sygn. W 14/94, Legalis nr 10240; wyrok TK z 8 IV 1997 r., sygn. K 14/96, Legalis nr 10353; wyrok TK z 9 VI 1998 r., sygn. K 28/97, Legalis nr 10441; wyrok TK z 12 III 2002 r., sygn. P 9/01, Legalis nr 53822. Przytoczony powyżej autor wskazuje ponadto, że prawo do sądu istnieje nawet wówczas, gdy jakaś ustawa regulująca prawa i obowiązki jednostki nie przewiduje możliwości wystąpienia na drogę sądową. Zob. też: wyrok SN z 7 IV 1999 r., sygn. I PKN 648/98, Legalis nr 44360; uchwała SN z 18 I 2001 r., sygn. III ZP 28/00, Legalis nr 48906. W takich wypadkach konstytucyjne prawo do sądu przysługuje stronie na podstawie dyrektywy bezpośredniego stosowania przepisów Konstytucji RP, która jest najwyższym prawem Rzeczypospolitej Polskiej (art. 8 Konstytucji RP). 
katalog tych podstaw (przesłanek) jest niezwykle szeroki i otwarty, pozostawiając organom uprawnionym znaczną swobodę oceny. Artykuł 89 $\S 1$ in principio ustawy o SN nie daje bowiem podstaw do jakiejkolwiek zawężającej wykładni tego przepisu, która pozwalałaby np. uznać, że ogranicza się on wyłącznie do wybranych zasad wynikających z art. 2 Konstytucji $\mathrm{RP}^{47}$. Nie powinno natomiast budzić wątpliwości, że omawiana podstawa skargi nadzwyczajnej (art. $89 \S 1$ in principio ustawy o SN) w przeciwieństwie do przesłanek określonych w art. 89 § 1 pkt 1-3 ustawy o SN, musi zostać spełniona i wykazana przez organ uprawniony w każdym wypadku ${ }^{48}$. Ma ona zatem charakter obligatoryjny ${ }^{49}$. Skarga nadzwyczajna niespełniająca wymogu wskazanego w art. $89 \S 1$ in principio ustawy o SN powinna zostać odrzucona bez wzywania do usunięcia braków ${ }^{50}$. Natomiast wykazanie omawianej podstawy wiązać się będzie z koniecznością merytorycznego rozpatrzenia skargi nadzwyczajnej przez SN w celu stwierdzenia, czy zasługuje ona na uwzględnienie ${ }^{51}$. W przeciwieństwie do skargi kasacyjnej wniesienie skargi nadzwyczajnej dopuszczalne jest bez względu na wartość przedmiotu zaskarżenia ${ }^{52}$.

${ }^{47} \mathrm{~W}$ tym kontekście niezwykle pożądane będzie więc, aby strony wnioskujące do podmiotów uprawnionych o wniesienie skargi nadzwyczajnej wskazywały, naruszenie których zasad, praw lub wolności wynikających z tego przepisu ich zdaniem powoduje konieczność zaskarżenia prawomocnego orzeczenia sądu powszechnego. Oczywiście, nie powinno to zwalniać tych organów z obowiązku wszechstronnego zbadania sprawy, a w szczególności nie wyklucza ewentualnego wniesienia skargi nadzwyczajnej na innych - niż wskazane przez stronę - podstawach. Niemniej pozwoliłoby to ukierunkować podmiot uprawniony w przedmiocie analizy sprawy.

${ }^{48} \mathrm{~W}$ uzasadnieniu do projektu nowelizacji ustawy o SN wskazano, że „w każdym przypadku łącznie z jedną z ww. przesłanek [chodzi o przesłanki wskazane w art. 89 $\S 1$ pkt 1-3 ustawy o SN - dop. B.W.] musi również zaistnieć przesłanka z art. 89 § 1 in principio ustawy o SN, co dodatkowo umacnia nadzwyczajny charakter skargi" (uzasadnienie do projektu nowelizacji ustawy o SN, s. 6).

${ }^{49} \mathrm{~W}$ tym kontekście warto zwrócić uwagę na podobne rozwiązanie przyjęte w odniesieniu do legitymacji organów publicznych do wniesienia odpowiednio skargi kasacyjnej (art. $398^{3}$ \& 2 k.p.c.) oraz skargi o stwierdzenie niezgodności z prawem prawomocnego orzeczenia (art. $424^{2}$ k.p.c.). Organy te - w przeciwieństwie do strony postępowania obwarowane zostały obowiązkiem wykazania dodatkowych przesłanek. Brak ich wykazania prowadzi do odrzucenia skargi kasacyjnej bez wzywania do usunięcia braków na podstawie art. $398^{6} \S 2$ lub 3 k.p.c., jako niespełniającej wymogów określonych w art. $398^{4} \S 1$ pkt 2 k.p.c. (A. Zieliński, Komentarz do art. 3983, w: Kodeks postępowania cywilnego. Komentarz, pod red. A. Zielińskiego, K. Flagi-Gieruszyńskiej, Warszawa 2017).

${ }^{50}$ Artykuł $89 \S 1$ in principio ustawy o SN w zw. z art. $398^{4} \S 1$ pkt 2 w zw. z art. $398^{6}$ $\S 2$ i 3 k.p.c. w zw. z art. 95 pkt 1 ustawy o SN.

${ }^{51}$ Artykuł 91 \& 1 ustawy o SN.

${ }^{52}$ Do skargi nadzwyczajnej nie znajdzie zastosowania art. $398^{2} \S 1-3$ k.p.c., gdyż kwestie te uregulowane zostały w art. 90 § 3 i 4 ustawy o SN. Skarga nadzwyczajna nie 
Kończąc, warto dodać, że na tle skargi kasacyjnej pewne wątpliwości budziła kwestia, czy pokrzywdzenie skarżącego orzeczeniem (gravamen), względnie interes prawny w zaskarżeniu określonego orzeczenia stanowią przesłankę jej dopuszczalności czy też merytoryczną przesłankę skuteczności (zasadności) tego środka odwoławczego ${ }^{53}$. Zagadnienie to rozstrzygnięte zostało przez SN, który stwierdził, że pokrzywdzenie orzeczeniem (gravamen) jest przesłanką dopuszczalności środka zaskarżenia, chyba że interes publiczny wymaga merytorycznego rozpoznania tego środka ${ }^{54}$. Wydaje się, że teza ta pozostaje w pełni aktualna na tle skargi nadzwyczajnej.

\subsection{Naruszenie zasad lub wolności i praw człowieka i obywatela określonych w Konstytucji RP}

Kolejną podstawą wniesienia skargi nadzwyczajnej jest wymóg, aby orzeczenie naruszało zasady lub wolności i prawa człowieka i obywatela określone w Konstytucji RP (art. 89 § 1 pkt 1 ustawy o SN). Podstawa ta ma charakter fakultatywny w tym sensie, że podmiot uprawniony może, lecz nie musi opierać skargi nadzwyczajnej na tej podstawie - może ją zatem oprzeć wyłącznie na podstawie art. $89 \S 1$ pkt 2 lub 3 ustawy o SN. Skarga nadzwyczajna niewskazująca żadnej z podstaw określonych w art. $89 \S 1$ pkt $1-3$ ustawy o SN powinna zostać odrzucona bez wzywania do usunięcia braków ${ }^{55}$.

\footnotetext{
jest natomiast dopuszczalna od wyroku ustalającego nieistnienie małżeństwa, orzekającego unieważnienie małżeństwa albo rozwód, jeżeli choćby jedna ze stron po uprawomocnieniu się takiego orzeczenia zawarła związek małżeński, oraz od postanowienia o przysposobieniu (art. $90 \S 3$ ustawy o SN). Nie jest też dopuszczalna w sprawach o wykroczenia i wykroczenia skarbowe (art. $90 \S 4$ ustawy o SN). Przepis ten zdaje się jednak dotyczyć wyłącznie skargi nadzwyczajnej w postępowaniu karnym (w sprawach karnych).

${ }^{53}$ A. Piotrowska, Komentarz do art. 3981, w: Kodeks postępowania cywilnego, t. 2: Komentarz. Art. 367-729, pod red. A. Marciniaka, K. Piaseckiego, Warszawa 2016.

${ }^{54}$ Uchwała Składu Siedmiu Sędziów SN z 15 V 2014 r., sygn. III CZP 88/13, Legalis nr 864626.

${ }_{55}$ Artykuł 89 § 1 pkt $1-3$ ustawy o SN w zw. z art. $398^{4} \S 1$ pkt 2 w zw. z art. $398^{6} \S 2$ i 3 k.p.c. w zw. z art. 95 pkt 1 ustawy o SN. Oczywiście, nie zmienia to faktu, że konieczne jest wykazanie podstawy głównej (art. 89 § 1 in principio ustawy o SN) i pozostałych obligatoryjnych przesłanek - musi istnieć substrat zaskarżenia w postaci prawomocnego orzeczenia sądu powszechnego lub sądu wojskowego kończącego postępowanie, które nie może być uchylone lub zmienione w trybie innych nadzwyczajnych środków zaskarżenia (art. 89 § 1 ustawy o SN).
} 
Poszukując dyrektyw wykładni art. 89 § 1 pkt 1 ustawy o SN, w pierwszej kolejności warto się odwołać do omawianego powyżej art. $398^{3}$ $\S 2$ k.p.c., a także do art. $424^{2}$ k.p.c., które określają dodatkowe podstawy wniesienia odpowiednio skargi kasacyjnej i skargi o stwierdzenie niezgodności z prawem prawomocnego orzeczenia dla organów publicznych ${ }^{56}$. Pomocne może być również odwołanie się do art. $424^{1}$ $\S 2$ oraz art. $519^{2} \S 2$ k.p.c., które - jakkolwiek w trochę innym kontekście - odwołują się do niezgodności z prawem wynikającej z naruszenia podstawowych zasad porządku prawnego lub konstytucyjnych wolności albo praw człowieka i obywatela ${ }^{57}$. Wskazuje się, że tego rodzaju klauzula stanowi klauzulę porządku publicznego, która mając charakter niedookreślony, daje sądowi dużą swobodę oceny takiej przesłanki ${ }^{58}$. Jakkolwiek literalna treść art. $89 \S 1$ pkt 1 ustawy o SN odwołuje się wyłącznie do zasad, wolności i praw określonych w Konstytucji RP ${ }^{59}$, zasadne wydaje się przyjęcie, że możliwe jest również wzięcie pod uwagę postanowień Konwencji o Ochronie Praw Człowieka i Podstawowych Wolności ${ }^{60}$ oraz Karty Praw Podstawowych UE ${ }^{61}$.

Omawiana podstawa skargi nadzwyczajnej, w szczególności w kontekście obligatoryjnej podstawy głównej (art. $89 \S 1$ in principio ustawy o SN) oraz pozostałych podstaw wskazanych w art. $89 \S 1$ pkt 2 i 3 ustawy o SN, budzi jednak wiele wattpliwości interpretacyjnych. Po pierwsze, przesłanka wskazana w art. $89 \S 1$ pkt 1 ustawy o SN - podobnie jak przesłanka wynikająca $z$ art. $89 \S 1$ in principio ustawy o $\mathrm{SN}-\mathrm{w}$ istocie

${ }^{56}$ Zob. przypis $49 \mathrm{w}$ niniejszym tekście.

${ }^{57}$ Przepisy te przewiduja, że w takich (wyjątkowych) wypadkach można także żądać stwierdzenia niezgodności z prawem prawomocnego wyroku (postanowienia co do istoty sprawy) sądu I lub II instancji kończącego postępowanie w sprawie, jeżeli strona nie skorzystała z przysługujących jej środków prawnych, chyba że jest możliwa zmiana lub uchylenie wyroku (postanowienia) w drodze innych przysługujących stronie środków prawnych.

${ }^{58}$ A. Zieliński, Komentarz do art. $424^{1}$, op. cit. Klauzula porządku publicznego przewidziana jest również $\mathrm{w}$ art. $1135 \S 2$ pkt 1 , art. $1135^{1} \S 1$, art. $1135^{2} \S 3$, art. $1146 \S 1$ pkt 7, art. 1152, art. $1206 \S 2$ pkt 2 oraz art. $1214 \S 3$ pkt 2 k.p.c., a także w art. 7 Ustawy z dnia 4 II 2011 r. Prawo prywatne międzynarodowe (Dz.U. 2011 Nr 80, poz. 432 ze zm.).

${ }^{59}$ Konstytucyjne wolności i prawa człowieka i obywatela zostały określone w art. 30-86 Konstytucji RP.

${ }^{60}$ Konwencja o Ochronie Praw Człowieka i Podstawowych Wolności sporządzona w Rzymie dnia 4 XI 1950 r., zmieniona następnie Protokołami nr 3, 5 i 8 oraz uzupełniona Protokołem nr 2 (Dz.U. 1993 Nr 61, poz. 284), dalej „Konwencja o Ochronie Praw Człowieka i Podstawowych Wolności".

${ }^{61}$ Choć z ostrożności procesowej w każdym wypadku w skardze nadzwyczajnej warto by również przywołać odpowiednie przepisy Konstytucji RP. 
ma charakter bardzo ogólnej klauzuli generalnej (klauzuli porządku publicznego). Odwołuje się bowiem do wszelkich zasad, praw i wolności wskazanych w Konstytucji RP. Swoim zakresem pokrywa się więc w dużej mierze z podstawą główną wskazaną w art. $89 \S 1$ in principio ustawy o SN. W praktyce oznacza to, że w wielu przypadkach ocena, że spełniona została podstawa główna, konsekwentnie prowadzić będzie do wniosku, iż równocześnie spełniona została fakultatywna podstawa wynikająca z art. $89 \S 1$ pkt 1 ustawy o SN. Oczywiście, w konkretnych okolicznościach (dodatkowo) możliwe będzie powołanie się na podstawę (lub podstawy) wskazane w art. 89 § 1 pkt 2 i 3 ustawy o SN, nie będzie to jednak wymóg konieczny. Taka wykładnia podważa wszakże sens kształtowania odrębnej przesłanki w art. $89 \S 1$ pkt 1 ustawy o SN, co stałoby w sprzeczności z zasadą racjonalnego ustawodawcy. Uchwycenie różnicy pomiędzy główną podstawą z art. $89 \S 1$ in principio ustawy o SN a podstawą fakultatywną z art. $89 \S 1$ pkt 1 ustawy o SN jest jednak niezwykle trudne ${ }^{62}$. Wprowadzenie przez ustawodawcę szerokiej podstawy fakultatywnej, określonej w art. $89 \S 1$ pkt 1 ustawy o SN, odwołującej się do ogólnych zasad wskazanych w Konstytucji RP, nie jest więc zabiegiem w pełni zrozumiałym, mając na uwadze równie szeroką treść obligatoryjnej podstawy głównej, wynikającej z art. 89 $\S 1$ in principio ustawy o SN. Ta przecież odwołuje się do najbardziej

${ }^{62}$ Porównanie treści tych przepisów może sugerować, że pierwsza z podstaw wyznacza cel (skutek), jaki organ powinien osiągnąć, wnosząc skargę nadzwyczajną, nie wymaga jednak, aby zaskarżane orzeczenie naruszało zasady wynikające z art. 2 Konstytucji RP. W takim ujęciu wniesienie skargi nadzwyczajnej (w konsekwencji czego zaskarżone orzeczenie zostałoby uchylone i SN orzekłby co do istoty sprawy lub przekazał sprawę do ponownego rozpoznania właściwemu sądowi), powinno zmierzać (być konieczne) do realizacji określonych wartości wynikających z tego przepisu. Ową konieczność należy zaś rozumieć jako brak możliwości osiągnięcia tego celu w inny sposób, co koresponduje z przesłanką braku możliwości uchylenia lub zmiany prawomocnego orzeczenia w trybie innych nadzwyczajnych środków zaskarżenia (art. 89 § 1 in fine ustawy o SN). Tymczasem art. $89 \S 1$ pkt 1 ustawy o SN wymaga, aby zaskarżane orzeczenie bezpośrednio naruszało zasady lub wolności i prawa człowieka i obywatela określone w Konstytucji RP. Powołując się na tę podstawę, organ powinien więc wykazać związek między zaskarżanym orzeczeniem a wartościami wynikającymi z tego przepisu, którym to orzeczenie uchybia. W praktyce wydaje się jednak bardzo mało prawdopodobne, aby w przypadku uznania przez uprawniony organ, iż w danej sprawie wniesienie skargi nadzwyczajnej jest konieczne w celu zapewnienia zgodności z zasadą demokratycznego państwa prawnego urzeczywistniającego zasady sprawiedliwości społecznej, zaskarżane orzeczenie równocześnie nie naruszało tych zasad. Przecież konieczność taka wynikać będzie właśnie z faktu, że charakter rozstrzygnięcia sądu godzi w zasady, prawa lub wolności wymagające ochrony. 
fundamentalnej zasady określonej w polskiej Konstytucji RP, z której wywodzone są wszelkie inne - zarówno te określone, jak i nieokreślone w Konstytucji - zasady, prawa i wolności. Z kolei przyjęcie, że podstawa określona w art. $89 \S 1$ pkt 1 ustawy o SN ma charakter obligatoryjny, wydaje się sprzeczne ze strukturą całego art. 89 § 1 ustawy o SN (podstawa ta wskazana została w odrębnym punkcie obok dwóch innych punktów określających fakultatywne podstawy skargi). Zresztą nawet przyjęcie, że podstawa ta ma charakter obligatoryjny, nie wyjaśniałoby, czym różni się ona od podstawy wskazanej w art. $89 \S 1$ in principio ustawy o SN. Na fakultatywny charakter podstawy z art. $89 \S 1$ pkt 1 (a zarazem pkt 2 i pkt 3) ustawy o SN wskazano zresztą wyraźnie w uzasadnieniu do nowelizacji ustawy o $\mathrm{SN}^{63}$.

Treść art. 89 § 1 pkt 1 ustawy o SN budzi również dalsze wątpliwości wynikające $z$ analizy funktorów logicznych (zdaniotwórczych), przyjętych w tym przepisie. Otóż literalna wykładnia tego przepisu zdaje się prowadzić do wniosku, że podstawa wniesienia skargi zaistnieje tylko wówczas, gdy orzeczenie naruszać będzie określone w Konstytucji RP: (1) zasady i prawa człowieka, (2) zasady i prawa obywatela, (3) wolności i prawa człowieka, (4) wolności i prawa obywatela, (5) zasady, wolności i prawa człowieka albo (6) zasady, wolności i prawa obywatela ${ }^{64}$. Niemniej proponowana wykładnia może budzić wątpliwości, gdyż nie jest jasne, dlaczego wniesienie skargi nadzwyczajnej miałoby być wykluczone w przypadku, gdy prawomocne orzeczenie naruszałoby: (1) zasady i wolności człowieka określone w Konstytucji RP albo (2) zasady i wolności obywatela określone w Konstytucji RP a więc wówczas, gdyby nie doszło do naruszenia praw człowieka lub obywatela określonych w Konstytucji RP. Warto zresztą pamiętać, że w konkretnych okolicznościach ścisłe rozgraniczenie praw i wolności

${ }^{63}$ Uzasadnienie do projektu nowelizacji ustawy o SN, s. 5 i 6 . Zob. też przypisy nr 35 i $48 \mathrm{w}$ niniejszym tekście.

${ }^{64} \mathrm{~W}$ przypadku "naruszenia zasad” $\mathrm{i}$ „wolności” zastosowano bowiem alternatywę przemienną (nierozłączną), co oznacza, że wystarczy, aby doszło do naruszenia jednego z tych elementów, aczkolwiek naruszone mogą być również oba z nich. Natomiast w odniesieniu do "naruszenia praw" zastosowano koniunkcję, a zatem warunek ten musi zostać bezwzględnie spełniony łącznie z jednym z pozostałych. Przyjęte rozumowanie oparte zostało ponadto na założeniu, iż sformułowanie "prawa człowieka i obywatela" rozumiane będzie odpowiednio jako „prawa człowieka” lub „prawa obywatela”. Przyjęcie odmiennego poglądu prowadziłoby do wniosku, że skarga nadzwyczajna stanowi środek służący ochronie wyłącznie obywateli. Pomijając dyskryminacyjny charakter takiej wykładni, w takim wypadku w ogóle nie byłoby konieczności odwoływania się w art. 89 $\S 1$ pkt 1 ustawy o SN do praw człowieka. 
może się okazać trudne zarówno w ujęciu teoretycznym, jak i praktycznym. Uwzględniając to, zasadne wydaje się przyjęcie, że naruszenie dowolnego elementu wskazanego w art. 89 § 1 pkt 1 ustawy o SN, a więc: (1) danej zasady lub zasad określonych w Konstytucji RP, (2) wolności określonych w Konstytucji RP, (3) prawa lub praw człowieka określonych w Konstytucji RP, albo wreszcie (4) prawa lub praw obywatela określonych w Konstytucji RP, legitymowałby podmiot uprawniony do wniesienia skargi nadzwyczajnej na tej podstawie ${ }^{65}$. Ponadto możliwa byłaby kombinacja powyższych naruszeń. Wadą proponowanego wariantu interpretacyjnego może być jego sprzeczność z literalnym brzmieniem art. $89 \S 1$ pkt 1 ustawy o $\mathrm{SN}$, a także rozszerzający charakter, co może być rozpatrywane jako sprzeczne z zasadą legalizmu ${ }^{66}$ oraz z postulatem, by skarga nadzwyczajna stanowiła środek zaskarżenia o wyjątkowym charakterze ${ }^{67}$.

\subsection{Rażące naruszenie prawa przez błędną jego wykładnię lub niewłaściwe zastosowanie}

Kolejna fakultatywna podstawa wniesienia skargi nadzwyczajnej wskazana została w art. $89 \S 1$ pkt 2 ustawy o SN. Wynika z niej, że zaskarżane orzeczenie musi rażąco naruszać prawo przez błędną jego wykładnię lub niewłaściwe zastosowanie. Podstawa ta zbliżona jest do podstawy skargi kasacyjnej określonej w art. $398^{3} \S 1$ pkt 1 k.p.c., aczkolwiek pojawiają się dwie istotne różnice.

Po pierwsze, art. $89 \S 1$ pkt 2 ustawy o SN ma szerszy charakter, gdyż mowa jest o naruszeniu prawa bez dookreślenia, o jaki rodzaj przepisów chodzi. Stąd, mimo istnienia odrębnej podstawy odnoszącej się do ustaleń faktycznych sądu (art. $89 \S 1$ pkt 3 ustawy o SN), a więc pośrednio mogącej się odnosić do uchybień przepisom postępowania, art. $89 \S 1$ pkt 2 ustawy o SN należałoby interpretować jako obejmujący wszelkiego rodzaju naruszenia prawa, w tym zwłaszcza naruszenia prawa materialnego, proceduralnego i ustrojowego ${ }^{68}$. Za taką wykładnią

${ }^{65}$ Naruszenie odpowiednio zasad i wolności może się odnosić się zarówno do człowieka, jak i obywatela.

${ }^{66}$ Artykuł 7 Konstytucji RP. Zob. też wyrok TK z 14 VI 2006 r., sygn. K 53/05, Legalis nr 75066.

${ }^{67}$ Zob. przypisy nr 27 i 28 w niniejszym tekście.

${ }^{68} \mathrm{Na}$ tle art. $156 \S 1$ pkt 2 k.p.a. wskazuje się, że „Pojęcie prawa w zwrocie «rażące naruszenie prawa» powinno być rozumiane szeroko, obejmując swoim zakresem przepisy 
przemawia również fakt, że w art. 89 § 1 ustawy o SN w ogóle brak jest podstawy, która odpowiadałaby podstawie skargi kasacyjnej określonej $\mathrm{w}$ art. $398^{3} \S 1$ pkt 2 k.p.c. (naruszenie przepisów postępowania, jeżeli uchybienie to mogło mieć istotny wpływ na wynik sprawy). Wydaje się więc, że podstawa ta inkorporowana jest w treści art. 89 § 1 pkt 2 ustawy o SN z tym zastrzeżeniem, że w przypadku skargi nadzwyczajnej prima facie $\mathrm{z}$ formalnego punktu widzenia mogłoby się wydawać, że nie ma konieczności wykazywania, iż naruszenie przepisów postępowania (lub jakichkolwiek innych) mogło mieć istotny wpływ na wynik sprawy. Artykuł $89 \S 1$ pkt 2 ustawy o SN nie zawiera bowiem explicite takiego wymogu. W praktyce jednak wykazanie takiego związku wydaje się pożądane (jeżeli nie konieczne ${ }^{69}$ ), należy wszak pamiętać, że treść art. $398^{3} \S 1$ pkt 2 k.p.c. ma głębokie uzasadnienie merytoryczne - brak jest bowiem podstaw do uchylania lub zmiany zaskarżanego orzeczenia, jeżeli mimo pewnych nieprawidłowości proceduralnych, finalnie i tak jest ono zgodne z prawem (sprawiedliwe) i nie narusza praw lub interesów strony ${ }^{70}$.

Naruszenie prawa może polegać na błędnej jego wykładni lub niewłaściwym zastosowaniu ${ }^{71}$. W tym zakresie aktualny pozostaje dorobek

prawa materialnego, procesowego oraz przepisy o charakterze ustrojowym (K. Glibowski, Komentarz do art. 156, w: Kodeks postepowania administracyjnego. Komentarz, pod red. R. Hausera, M. Wierzbowskiego, Warszawa 2018, za: J. Borkowski, w: B. Adamiak, J. Borkowski, Komentarz, 2009, s. 599). Zob. też wyrok Wojewódzkiego Sądu Administracyjnego (WSA) w Rzeszowie z 8 V 2014 r., sygn. II SA/Rz 194/14, Legalis nr 979578, w którym sąd stwierdził, że: „ «Naruszenie prawa» to naruszenie prawa materialnego, procesowego, oraz przepisów o charakterze ustrojowym i kompetencyjnym. Można wobec tego stwierdzić, że chodzi o wszystkie normy prawne regulujące działanie administracji publicznej w indywidualnych sprawach, niezależnie od tego, z jakich przepisów prawa się wywodzą".

${ }^{69} \mathrm{~W}$ doktrynie wskazuje się, że „Konieczność wykazania związku przyczynowego danego naruszenia z treścią zaskarżonego orzeczenia wynika wprost ze sformułowania art. $89 \S 1$ pkt 2 ustawy o SN, w którym mowa jest o orzeczeniu naruszającym prawo w sposób rażący. Podobnie uwzględnienie skargi nadzwyczajnej opartej na podstawie przewidzianej w art. 89 § 1 pkt 3 ustawy o SN wymaga wykazania nie tylko oczywistej sprzeczności istotnych ustaleń sądu z treścią zebranego w sprawie materiału dowodowego, ale także związku przyczynowego tego rodzaju wady z treścią zaskarżonego orzeczenia" (R.M. Bełczącki, Rozpoznanie skargi nadzwyczajnej...).

${ }^{70}$ Przykładowo, zgodnie z art. $398^{14}$ in fine k.p.c. SN oddala skargę kasacyjną, jeżeli zaskarżone orzeczenie mimo błędnego uzasadnienia odpowiada prawu.

${ }^{71} \mathrm{Na}$ tle podstawy skargi kasacyjnej określonej w art. $398^{3} \S 1$ pkt 1 k.p.c. wskazuje się, $\dot{z ̇ e}$ „[...] naruszenie prawa materialnego może występować w trzech postaciach: błędnej (niewłaściwej) interpretacji (wykładni) istniejącej normy prawa materialnego; zastosowania nieistniejącej normy prawa materialnego oraz błędu w subsumcji, czyli błędnego przyjęcia istnienia lub nieistnienia związku pomiędzy ustalonym przez sąd stanem faktycznym danej sprawy a określoną normą prawną" (A. Zieliński, Komentarz do art. 39833). 
orzeczniczy i naukowy wypracowany na tle art. $398^{3} \S 1$ pkt 1 k.p.c. Błędna wykładnia (interpretacja) przepisu zasadniczo polegać będzie na mylnym rozumieniu treści lub znaczenia przepisu prawa, $w$ tym także zawartych w normie pojęć odwołujących się do wartościujących ocen pozaprawnych $^{72}$. Naruszenie prawa przez niewłaściwe zastosowanie może natomiast polegać na wadliwej subsumcji, czyli na nieprawidłowym przyjęciu przez sąd, że ustalony w sprawie stan faktyczny odpowiada hipotezie określonej normy prawnej lub na błędnym określeniu skutków płynących z "podciągnięcia” ustalonego stanu faktycznego pod właściwą normę prawną ${ }^{73}$. Mimo pewnych sporów w tym zakresie wydaje się, że błędna wykładnia i niewłaściwe zastosowanie prawa mogą także zachodzić równocześnie ${ }^{74}$.

Po drugie, art. $89 \S 1$ pkt 2 ustawy o SN ma charakter zawężający, gdyż mowa jest o rażącym naruszeniu prawa. Naruszenie to musi mieć zatem charakter kwalifikowany. Pojawia się więc pytanie, czy wykazanie istotnego wpływu na wynik sprawy będzie w tym zakresie wystarczające $^{75}$. Kodeks postępowania cywilnego posługuje się pojęciem rażącego naruszenia prawa tylko w dwóch wypadkach - w art. $477^{14}$ $\S 3$ i art. $479^{31} \S 3$ - czyniąc to jednak w odniesieniu odpowiednio do decyzji wojewódzkiego zespołu do spraw orzekania o niepełnosprawności oraz do decyzji Prezesa UOKiK ${ }^{76}$. Nie przewiduje zatem regulacji, która nakazywałaby uchylić lub zmienić orzeczenie wydane przez sąd, przyjmując za podstawę fakt, że narusza ono prawo w stopniu rażącym. W tym kontekście można się odwołać do przyjmowanej w orzecznictwie

${ }^{72}$ A. Piotrowska, Komentarz do art. $398^{3}$. Autorka dodaje, że jest to niewłaściwa interpretacja przepisu odbiegająca od wyniku prawidłowego zastosowania przyjętych ogólnie reguł wykładni przepisów prawa oraz dorobku doktryny i orzecznictwa. Zob. też wyrok SN z 19 I 1998 r., sygn. I CKN 424/97, Legalis nr 32153, w którym sąd stwierdził: „[...] naruszenie prawa materialnego będące następstwem błędnej jego wykładni można określić jako nadanie innego znaczenia treści zastosowanego przepisu, czyli polega na mylnym zrozumieniu poszczególnego zwrotu lub treści i tym samym znaczenia przepisu lub też tylko terminu występującego w jego treści. Omawiana postać naruszenia prawa materialnego przez błędną jego wykładnię obejmuje także ustalenie rzeczywistej treści ogólnych pojęć prawnych, do których należą zasady współżycia społecznego [...]".

${ }^{73}$ A. Piotrowska, Komentarz do art. $398^{3}$.

${ }^{74}$ Ibidem. W takim wypadku chodzi o sytuację, w której sąd najpierw dokonał wadliwej wykładni określonego przepisu, a następnie, na skutek tej wadliwej wykładni, zastosował $\mathrm{w}$ danym stanie faktycznym, chociaż nie powinien, tenże przepis.

${ }^{75}$ Zob. przypis $69 \mathrm{w}$ niniejszym tekście.

${ }^{76}$ Co więcej, na tle wskazanych przepisów k.p.c. brak jest wypowiedzi w doktrynie czy judykaturze, które wskazywałyby, jak należałoby rozumieć pojęcie „rażącego naruszenia prawa". 
SN wykładni art. $424^{1} \S 1$ k.p.c., który przewiduje podstawy dopuszczalności skargi o stwierdzenie niezgodności z prawem prawomocnego orzeczenia. Jakkolwiek przepis ten nie odwołuje się w żaden sposób do pojęcia "rażącego naruszenia prawa" (mowa jest o tym, że przez wydanie stronie została wyrządzona szkoda, a zmiana lub uchylenie tego wyroku w drodze przysługujących stronie środków prawnych nie było i nie jest możliwe), w orzecznictwie SN przyjmuje się, że zasadność skargi aktualizuje się w sytuacji, w której niezgodność ta - w rozumieniu art. $424^{1}$ k.p.c. $w$ zw. $z$ art. $417 \S 1$ i art. $417^{1} \S 2$ k.p.c. - polega na oczywistej i rażącej obrazie prawa, niebudzącej żadnych wątpliwości ${ }^{77}$. Zasadne może być również - aczkolwiek czynione powinno być z dużą ostrożnością - odwołanie się do innych aktów prawnych w tej materii. Pojęciem rażącego naruszenia prawa posługuje się np. Kodeks postępowania administracyjnego ${ }^{78}$ (art. $37 \S 6$ pkt 1, art. $139^{79}$ i art. $156 \S 1$ pkt 2$)^{80}$. W tym zakresie najbardziej odpowiednie wydaje się

77 Wyrok SN z 25 III 2009 r., sygn. V CNP 93/08, Legalis nr 186573. W wyroku SN z 31 III 2006 r., sygn. IV CNP 25/05, Legalis nr 79746, sąd wskazał: „Pojęcie niezgodności z prawem $\mathrm{w}$ rozumieniu art. $424^{1}$ k.p.c. powinno więc być wykładane zgodnie z tymi uwarunkowaniami, w związku z czym niezgodność z prawem może wynikać tylko ze skrajnych, oczywistych błędów sądu polegających na rażącym naruszeniu zasad wykładni lub stosowania prawa". Zob. też: wyrok SN z 24 VII 2006 r., sygn. I BP 1/06, Legalis nr 85806; wyrok SN z 4 I 2007 r., sygn. V CNP 132/06, Legalis nr 82053; wyrok SN z 21 II 2007 r., sygn. I CNP 71/06, Legalis nr 174333.

${ }^{78}$ Ustawa z dnia 14 VI 1960 r. Kodeks postępowania administracyjnego (tekst jedn. Dz.U. 2017, poz. 1257), dalej „k.p.a.”.

${ }^{79} \mathrm{~W}$ doktrynie sporne jest, czy pojęcie „rażącego naruszenia prawa”, o którym mowa $\mathrm{w}$ art. 139 k.p.a., należy rozumieć zgodnie z przyjętym w orzecznictwie sądowym znaczeniem tego pojęcia zawartym w art. $156 \S 1$ pkt 2 k.p.a., czy też że jest ono szersze od pojęcia rażącego naruszenia prawa będącego podstawą stwierdzenia nieważności decyzji (art. $156 \S 1$ pkt 2 k.p.a.) i obejmuje wszystkie kwalifikowane wypadki naruszenia prawa wymienione taksatywnie w art. $145 \S 1$, art. 145a $\S 1$ i art. $156 \S 1$ k.p.a. (K. Glibowski, Komentarz do art. 156). Zob. też wyrok WSA w Warszawie z 24 III 2005 r., sygn. VI SA/ Wa 1149/04, Legalis nr 271023.

${ }^{80}$ Warto zaznaczyć, że również przepisy Ustawy z dnia 30 VIII 2002 r. Prawo o postępowaniu przed sądami administracyjnymi (tekst jedn. Dz.U. 2018, poz. 1302), dalej „p.p.s.a.”, posługują się pojęciem "rażącego naruszenia prawa" (art. 54 § 3, art. 145a § 3, art. 149 $\S 1$ a, art. 154 \& 2, art. 285a § 3 p.p.s.a.). Przepisy te $-\mathrm{z}$ wyjątkiem art. $285 a$ \& 3 p.p.s.a. odnoszą się jednak do art. 6 Ustawy z dnia 20 I 2011 r. o odpowiedzialności majątkowej funkcjonariuszy publicznych za rażące naruszenie prawa (Dz.U. Nr 34, poz. 173 ze zm.). $\mathrm{Na}$ tle art. 285a § 3 p.p.s.a. wskazuje się natomiast, że orzeczeniem niezgodnym z prawem w rozumieniu tego przepisu będzie takie orzeczenie, które jest niewątpliwie sprzeczne z zasadniczymi i niepodlegającymi różnej wykładni przepisami oraz z ogólnie przyjętymi standardami rozstrzygnięć albo które zostało wydane w wyniku szczególnie rażąco błędnej wykładni lub niewłaściwego zastosowania prawa. Innymi słowy, naruszenie prawa musi 
odwołanie do wykładni art. $156 \S 1$ pkt 2 k.p.a., zgodnie z którym organ administracji publicznej stwierdza nieważność decyzji, która wydana została bez podstawy prawnej lub z rażącym naruszeniem prawa. Na tle tego przepisu przyjmuje się, że rażące naruszenie prawa zachodzi w dwóch wypadkach. Po pierwsze, gdy chodzi o naruszenie przepisu niepozostawiającego wątpliwości co do jego bezpośredniego rozumienia - naruszenie musi być więc oczywiste, wyraźne, bezsporne ${ }^{81}$. Można zatem o nim mówić tylko wówczas, gdy przepis nie budzi wątpliwości interpretacyjnych, natomiast proste zestawienie treści rozstrzygnięcia z treścią zastosowanego przepisu prawa wskazuje na ich oczywistą niezgodność ${ }^{82}$. Po drugie, dopuszcza się również możliwość - choć kwestia ta w doktrynie jest sporna ${ }^{83}$ - aby przy wykładni pojęcia "rażącego naruszenia prawa" brać pod uwagę skutki (np. ekonomiczne, gospodarcze lub społeczne) naruszenia prawa ${ }^{84}$. W takim ujęciu orzeczenie rażąco naruszać będzie prawo, jeżeli skutki tego naruszenia będą niemożliwe do zaakceptowania z punktu widzenia praworządności ${ }^{85}$. Takie podej-

być elementarne i oczywiste, a jego stwierdzenie nie powinno wymagać głębszej analizy prawnej. W szczególności wybór jednej z możliwych - przy zastosowaniu powszechnie przyjętych metod wykładni - interpretacji przepisów prawa, choćby okazała się ona w ocenie Naczelnego Sądu Administracyjnego (NSA) nieprawidłowa, nie oznacza niezgodności orzeczenia z prawem (J. Drachal, A. Wiktorowska, G. Rząsa, Komentarz do art. 285a, w: Prawo o postepowaniu przed sadami administracyjnymi. Komentarz, pod red. R. Hausera, M. Wierzbowskiego, Warszawa 2017). Zob. wyrok NSA z 26 VI 2014 r., sygn. I FNP 5/14, Legalis nr 1043160; wyrok NSA z 26 VIII 2011 r., sygn. I GNP 1/11, Legalis nr 382865. W art. 55 § 3 p.p.s.a. mowa jest natomiast o "rażących przypadkach naruszenia obowiązków”.

${ }^{81}$ K. Glibowski, Komentarz do art. 156.

${ }^{82}$ Wyrok NSA z 11 V 1994 r., sygn. III SA 1705/93, Legalis nr 38548; wyrok NSA z 5 IV 1996 r., sygn. III SA 529/95, Legalis nr 42009; wyrok NSA z 17 IV 1996 r., sygn. III SA 565/95, Legalis nr 46457; wyrok NSA z 9 II 2005 r., sygn. OSK 1134/04, Legalis nr 76089; wyrok NSA z 8 IX 2009 r., sygn. II GSK 1061/08, Legalis nr 820738; wyrok NSA z 23 V 2017 r., sygn. II OSK 1769/16, Legalis nr 1680755; wyrok WSA w Warszawie z 6 IX 2017 r., sygn. VII SA/Wa 2010/16, Legalis nr 1668934; wyrok Sądu Apelacyjnego w Szczecinie z 8 V 2014 r., sygn. III AUa 892/13, Legalis nr 1217387.

${ }^{83}$ K. Glibowski, Komentarz do art. 156.

${ }^{84}$ Wskazuje się przy tym, że "Skutki społeczno-gospodarcze mogą być traktowane jako kryterium kwalifikowania naruszenia prawa jako rażącego, jednak przede wszystkim należy stwierdzić naruszenie prawa i dopiero oceniać je jako rażące przez pryzmat skutków prawnych wywołanych przez wadliwą decyzję (K. Glibowski, Komentarz do art. 156, za: A. Wróbel, w: K. Chorąży, W. Taras, A. Wróbel, Postępowanie administracyjne, egzekucyjne, sądowoadministracyjne, Kraków 2003, s. 190-191). Zob. też wyrok NSA z 9 II 2005 r., sygn. OSK 1134/04, Legalis nr 76089.

${ }^{85}$ K. Glibowski, Komentarz do art. 156. W wyroku NSA z 21 IX 2017 r., sygn. II OSK 83/16, Legalis nr 1710252, sąd stwierdził: „W orzecznictwie sądów administracyjnych 
ście należy uznać za słuszne. Może się bowiem zdarzyć, że jakkolwiek naruszenie prawa samo przez się nie będzie miało charakteru oczywistego, to jednak wynikające $z$ tego negatywne dla strony konsekwencje okażą się znaczące. Nie byłoby więc zasadne, aby w takich okolicznościach wykluczać możliwość wniesienia skargi nadzwyczajnej, wszak wydaje się, że intencją wprowadzenia tego instrumentu było właśnie umożliwienie wzruszania takich orzeczeń, które nie będąc podważalne żadnymi innymi środkami, wyrządziły lub wyrządzają stronie znaczną szkodę lub krzywdę. Należy podkreślić, że omawiane sposoby wykładni pojęcia "rażącego naruszenia prawa” wypracowane zostały na tle przepisów k.p.a., a więc w odniesieniu do decyzji administracyjnych. Niemniej, wobec tego, że na gruncie prawa postępowania cywilnego treść art. $89 \S 1$ pkt 2 ustawy o SN w omawianym zakresie zdaje się mieć charakter odosobniony, wydaje się, że dorobek naukowy i orzeczniczy wypracowany w tej materii (a w szczególności na tle art. $156 \S 1$ pkt 2 k.p.a.) może stanowić wskazówkę interpretacyjna, albo przynajmniej punkt wyjścia dla wykładni art. $89 \S 1$ pkt 2 ustawy o SN. Ponadto dyrektyw wykładni w omawianym zakresie można również poszukiwać w przepisach Kodeksu cywilnego ${ }^{86}$, które w wielu miejscach w różnym kontekście posługują się pojęciem "rażący"87. Wydaje się, że w szcze-

przyjmuje się, że rażące naruszenie prawa ma miejsce wtedy, gdy treść decyzji pozostaje w wyraźnej i oczywistej sprzeczności z brzmieniem konkretnego przepisu prawa oraz gdy charakter tego naruszenia powoduje, że decyzja ta wywołuje skutki społeczno-gospodarcze niemożliwe do zaakceptowania z punktu widzenia wymagań praworządności. Od rażącego naruszenia prawa (kwalifikowanego) należy natomiast odróżnić każde inne naruszenie prawa". Podobnie wyrok NSA z 20 X 2017 r., sygn. II OSK 305/16, Legalis nr 1755474. Zob. też wyrok NSA z 3 IV 2009 r., sygn. II OSK 479/08, Legalis nr 219358. Natomiast w wyroku NSA z 6 IX 1984 r., sygn. II SA 737/84, Legalis nr 35365, sąd stwierdził: „O tym, czy naruszenie prawa jest naruszeniem «rażącym», decyduje ocena skutków społeczno-gospodarczych, jakie dane naruszenie za sobą pociąga. Za «rażące» uznać należy mianowicie takie naruszenie prawa, w wyniku którego powstają skutki niemożliwe do zaakceptowania z punktu widzenia praworządności. Nie ma tu natomiast rozstrzygającego znaczenia ani oczywistość naruszenia określonego przepisu, ani nawet charakter przepisu, który został naruszony".

${ }^{86}$ Ustawa z dnia 23 kwietnia 1964 r. - Kodeks cywilny (tekst jedn. Dz.U. 2018, poz. 1025), dalej „k.c.”.

${ }^{87} \mathrm{~W}$ Kodeksie cywilnym mowa jest o rażącym pokrzywdzeniu osoby (art. $14 \S 2$ k.c.), rażącej sprzeczności czynności z zasadami prawidłowego zarządu (art. 202 k.c.), rażącym uchybieniu przy wykonywaniu swojego prawa (art. 303 k.c.), rażącej stracie (art. $357^{1}$ i art. 632 k.c.), rażącym naruszeniu interesów konsumenta (art. $385^{1} \S 1$ k.c.), rażącym wygórowaniu kary umownej (art. $385^{3}$ pkt 17, art. 484 § 2 k.c.), rażąco krótkim terminie (art. $385^{3}$ pkt 18 k.c.), wartości świadczenia przewyższającej w rażącym stopniu wartość 
gólności sposób wykładni pojęcia „rażącego naruszenia interesów konsumenta" 88 czy "rażącego niedbalstwa" ${ }^{\prime \prime 9}$ stanowić może przydatną wskazówkę w przedmiocie interpretacji art. 89 § 1 pkt 2 ustawy o SN.

Kończąc, warto także zasygnalizować, że przesłanka rażącego naruszenia prawa (jeżeli mogło ono mieć istotny wpływ na treść orzeczenia) stanowi jedną z podstaw kasacji w postępowaniu karnym (art. 523 § 1 k.p.k.). W doktrynie wskazuje się, że rażące naruszenie prawa wystąpić może jedynie w przypadku, gdy organ stosujący to prawo dokona wykładni ewidentnie błędnej - chodzi więc o oczywiste naruszenie prawa, które powinno być do uchwycenia na "na pierwszy rzut oka"90. Z kolei w postanowieniu z 3 X 2006 r., sygn. IV KK 197/06, Legalis nr 83632, SN przyjął, że przez rażące naruszenie prawa należy rozumieć takie uchybienie, którego skutkiem jest pogorszenie sytuacji oskarżonego w porównaniu z ta, w której znalazłby się on, gdyby odpowiednie przepisy zastosowano w sposób prawidłowy. Uwagi w tym zakresie czynione są na marginesie, wszak odwoływanie się w tym przypadku do wykładni przepisów prawa karnego powinno być czynione z ostrożnością.

\subsection{Oczywista sprzeczność istotnych ustaleń sądu z treścią zebranego w sprawie materiału dowodowego}

Ostatnią fakultatywną podstawą skargi nadzwyczajnej jest oczywista sprzeczność istotnych ustaleń sądu z treścią zebranego w sprawie materiału dowodowego (art. $89 \S 1$ pkt 3 ustawy o SN). Wprowadza ona zatem

świadczenia wzajemnego (art. 388 § 1 k.c.), wykraczaniu w sposób rażący przeciwko obowiązującemu porządkowi domowemu (art. 685 k.c.), rażącym niedbalstwie (art. 757, art. $777 \S 1$, art. $788 \S 1$ i 3 , art. 791 , art. $801 \S 1$ i 3, art. $818 \S 3$, art. $826 \S 3$, art. $827 \S 1$, art. 849 $\S 2$, art. 852 , art. $855 \S 4$, art. $859^{8} \S 2$ oraz art. $891 \S 1$ k.c.), rażących brakach (art. $781 \S 1$ k.c.), rażącej niewdzięczności (art. 898 § 1 k.c.) i rażącej obrazie czci (art. 1008 pkt 2 k.c.).

${ }^{88}$ Wyrok SN z 13 VII 2005 r., sygn. I CK 832/04, Legalis nr 71468; wyrok SN z 13 VIII 2015 r., sygn. I CSK 611/14, Legalis nr 1325760; wyrok SN z 15 I 2016 r., sygn. I CSK 125/15, Legalis nr 1398255; wyrok SN z 8 IX 2016 r., sygn. II CSK 750/15, Legalis nr 1555664.

${ }^{89}$ Pojęcie rażącego niedbalstwa stanowi typową klauzulę generalną. Rażąco niedbałym będzie zarówno takie zachowanie osoby, która przewiduje skutki swojego działania lub zaniechania, lecz spodziewa się, że ich uniknie (lekkomyślność), jak i sytuacja, w której osoba skutków tych nie przewiduje, chociaż może i powinna była je przewidzieć, mając jednak na uwadze minimalny standard staranności (tak na tle wykładni art. 827 $\S 1$ k.c. SN w wyroku z 11 V 2005 r., sygn. III CK 522/04, Legalis nr 265933). Zob. też wyrok SN z 10 III 2004 r., sygn. IV CK 151/03, LEX nr 151642.

${ }^{90}$ A. Sakowicz, M. Warchoł, Komentarz do art. 523, w: Kodeks postepowania karnego. Komentarz, pod red. A. Sakowicza, Warszawa 2016. 
istotną różnicę w porównaniu ze skargą kasacyjną, której podstawą nie mogą być zarzuty dotyczące ustalenia faktów lub oceny dowodów (art. $398^{3}$ § 3 k.p.c.). Warto jednak zaznaczyć, że mimo zakazu wynikającego z art. $398^{3} \S 3$ k.p.c., na tle skargi kasacyjnej, w orzecznictwie SN dopuszcza się możliwość wniesienia zarzutu braku lub niedostatku ustaleń faktycznych jako usprawiedliwienie zarzutu naruszenia prawa materialnego ${ }^{91}$. Podstawą takiego zarzutu - jakkolwiek stwierdza on brak dokonania odpowiednich (niezbędnych) ustaleń faktycznych - będzie jednak art. $398^{3} \S 1$ pkt 1 k.p.c. SN dopuszcza również kwestionowanie oceny dowodów stanowiącej podstawę ustaleń faktycznych, ale tylko wówczas, gdy oparta została na materiale dowodowym zebranym z naruszeniem przepisów regulujących postępowanie dowodowe ${ }^{92}$. Chodzi o zarzuty dotyczące prawidłowości sposobu, w jaki sąd dokonał ustaleń faktycznych ${ }^{93}$, a więc tego, w jaki sposób gromadził materiał dowodowy i ustalał fakty, tj. poprzez niedopuszczenie określonego dowodu, nieprawidłowe przeprowadzenie dowodu lub pominięcie dowodu. W takich wypadkach podstawą zarzutu będzie art. $398^{3} \S 1$ pkt 2 k.p.c., a więc naruszenie przepisów postępowania, przy czym konieczne będzie wykazanie, że uchybienie to mogło mieć istotny wpływ na wynik sprawy ${ }^{94}$. Ze względu na treść art. $398^{3} \S 3$ k.p.c. niedopuszczalna jest natomiast polemika przez skarżącego z wynikami oceny dowodów przeprowadzonej

${ }^{91} \mathrm{~W}$ orzecznictwie SN przyjmuje się, że naruszenie prawa materialnego przez jego niewłaściwe zastosowanie $\mathrm{w}$ rozumieniu art. $398^{3} \S 1$ pkt 1 k.p.c. ma miejsce również w przypadku, gdy wyrok sądu II instancji nie zawiera ustaleń faktycznych odnoszących się do przesłanek stosowanej normy prawa materialnego (wyrok SN z 18 I 2012 r., sygn. II PK 117/11, Legalis nr 478602). Podobnie w doktrynie wskazuje się, że „Pominięcie przy wyrokowaniu dowodu, którym sąd dysponował, ale którego nie ocenił, a także nie rozważył jego znaczenia dla wyniku sprawy, może być przedmiotem zarzutu naruszenia art. $316 \S 1$. Sąd nie wziął bowiem pod uwagę istniejącego w chwili wyrokowania stanu rzeczy, do czego zobowiązuje go art. 316, lecz w istocie oparł rozstrzygnięcie na stanie rzeczy innym, bo nieuwzględniającym jednego z dowodów znajdujących się w dostępnym sądowi materiale dowodowym (por. wyrok SN z 16 III 2007 r., III CSK 357/06, Legalis nr 162807)" (A. Piotrowska, Komentarz do art. 3983).

${ }^{92}$ Wyrok SN z 8 XI 2005 r., sygn. I CK 178/05, Legalis nr 354639. Sąd dodał, że w takim wypadku obowiązkiem skarżącego jest przytoczenie tych przepisów i wyjaśnienie, jaki wpływ na treść rozstrzygnięcia miało naruszenie przepisów.

${ }^{93}$ A. Piotrowska, Komentarz do art. 3983. Zob. też wyrok SN z 16 III 2006 r., sygn. III CSK 17/06, Legalis nr 108224; wyrok SN z 4 II 2015 r., sygn. IV CSK 183/14, Legalis nr 1231804; postanowienie SN z 4 IX 2014 r., sygn. II CSK 659/13, Legalis nr 1092044.

${ }^{94} \mathrm{~W}$ ramach tej podstawy SN dopuścił również możliwość oparcia skargi kasacyjnej na podstawie zarzutu naruszenia art. 328 \& 2 oraz art. 378 § $1 \mathrm{w}$ zw. z art. 391 § 1 k.p.c. (wyrok SN z 30 III 2012 r., sygn. III CSK 217/11, Legalis nr 526820). 
przez sąd II instancji lub kwestionowanie prawidłowości ustaleń tego sądu stanowiących podstawę faktyczną zaskarżonego orzeczenia ${ }^{95}$. Tymczasem art. $89 \S 1$ pkt 3 ustawy o SN wprost stanowi, że sprzeczność ustaleń sądu z treścią zebranego w sprawie materiału dowodowego może stanowić podstawę wniesienia skargi nadzwyczajnej. Wymaga przy tym, aby sprzeczność ta była oczywista, a ustalenia sądu istotne dla rozstrzygnięcia. Oznacza to, że w zakresie rozpatrywania skargi nadzwyczajnej wniesionej na podstawie art. $89 \S 1$ pkt 3 ustawy o SN sąd ten przestaje być jedynie "sądem prawa”, ale staje się również (może się stać) "sądem faktu”. Nie jest więc związany ustalonym przez sądy niższych instancji stanem faktycznym sprawy. Warto przy tym zwrócić uwagę, że w art. $89 \S 1$ pkt 3 ustawy o SN mowa jest wyłącznie o ustaleniach sądu, przepis ten nie odnosi się natomiast do oceny dowodów. Dla porównania, art. $398^{3} \S 3$ k.p.c. odwołuje się zarówno do ustalenia faktów, jak i oceny dowodów. Pojawia się zatem pytanie, czy dopuszczalne jest opieranie skargi nadzwyczajnej na zarzucie nieprawidłowej oceny dowodów. Literalne brzmienie art. $89 \S 1$ pkt 3 ustawy o SN mogłoby sugerować, że nie ma takiej możliwości. Takie stanowisko nie wydaje się jednak przekonujące. Po pierwsze, kwestia ustalenia faktów często będzie nierozerwalnie związana z oceną dowodów. Po drugie, brak jest normy, która by explicite (na wzór art. $398^{3} \S 3$ k.p.c.) zakazywała

${ }^{95}$ A. Piotrowska, Komentarz do art. $398^{3}$. Autorka wskazuje również, że "Nie jest dopuszczalne formułowanie w skardze kasacyjnej zarzutów naruszenia art. $228 \S 1,229$, 230, czyli przepisów postępowania dotyczących ustalania faktów bez przeprowadzania postępowania dowodowego oraz zarzutu naruszenia art. $233 \S 1$ odnoszącego się do oceny dowodów. [...] Za niedopuszczalny należy uznać zarzut naruszenia art. 231 dotyczącego możliwości stosowania domniemania faktycznego, tj. ustalenia określonego faktu na podstawie innych ustalonych faktów". W wyroku SN z 8 III 2010 r., sygn. II PK 260/09, Legalis nr 373884) sąd stwierdził, że: „Przepis art. 398 \& 3 k.p.c. wprawdzie nie wskazuje expressis verbis konkretnych przepisów, których naruszenie, w związku z ustaleniem faktów i przeprowadzeniem oceny dowodów, nie może być przedmiotem zarzutów wypełniających drugą podstawę kasacyjną, nie ulega jednak wątpliwości, że obejmuje on art. 233 k.p.c. [...] każdy zarzut skargi kasacyjnej, który ma na celu polemikę z ustaleniami faktycznymi sądu II instancji, chociażby pod pozorem błędnej wykładni lub niewłaściwego zastosowania określonych przepisów prawa materialnego, z uwagi na jego sprzeczność z art. $398^{3} \S 3$ k.p.c., jest a limine niedopuszczalny". Zob. też: wyrok SN z 16 XI 2012 r., sygn. III CSK 73/12, Legalis nr 667406; wyrok SN z 13 XII 2012 r., sygn. III UK 17/12, Legalis nr 569555. Natomiast w wyroku SN z 10 V 2012 r., sygn. II PK 220/11, Legalis nr 507158, sąd stwierdził: „Art. 227 k.p.c. nie może być przedmiotem naruszenia sądu odwoławczego, gdyż przepis ten nie jest źródłem obowiązków ani uprawnień jurysdykcyjnych, lecz określa jedynie wolę ustawodawcy ograniczenia kręgu faktów, które mogą być przedmiotem dowodu w postępowaniu cywilnym". 
opierania skargi nadzwyczajnej na zarzucie nieprawidłowej oceny dowodów. Nawet jeżeli więc przyjąć, że nie będzie to możliwe na podstawie art. $89 \S 1$ pkt 3 ustawy o SN, to wydaje się, że brak przeszkód, aby zarzut taki oprzeć na podstawie art. $89 \S 1$ pkt 2 ustawy o $\mathrm{SN}^{96}$. W każdym razie podmiot uprawniony powinien wykazać, że ocena dowodów dokonana przez sąd nastąpiła $z$ uchybieniem odpowiednich przepisów k.p.c. w tym zakresie (np. z uchybieniem art. 233 k.p.c.). Podważenie legalności oceny materiału dowodowego wymaga przy tym wykazania, jakie kryteria oceny zostały naruszone ${ }^{97}$, w przeciwnym razie stanowi niedopuszczalną polemikę z ustaleniami i oceną materiału dowodowego dokonaną przez sąd w sprawie ${ }^{98}$. Wychodząc $z$ takich założeń, art. $398^{3}$ $\S 3$ k.p.c. nie znajdzie zastosowania do skargi nadzwyczajnej.

W kontekście powyższego pojawia się pytanie, czy w skardze nadzwyczajnej dopuszczalne jest powołanie nowych faktów i dowodów ${ }^{99}$. W doktrynie wyrażono pogląd, że w przypadku skargi nadzwyczajnej takiej możliwości nie ma - wskazuje się, że zakaz powołania nowych faktów i dowodów można wywieść z art. $398^{13} \S 2$ in principio k.p.c. w zw. z art. 95 pkt 1 ustawy o $\mathrm{SN}^{100}$. Za zakazem może również przemawiać fakt, że w art. $89 \S 1$ pkt 3 ustawy o SN mowa jest o materiale dowodowym zebranym w sprawie ${ }^{101}$. Biorąc jednak pod uwagę, iż skarga

${ }^{96}$ Warto zaznaczyć, że przywołanie w skardze nadzwyczajnej prawidłowej jednostki redakcyjnej art. 89 ustawy o SN nie powinno mieć decydującego znaczenia dla oceny jej dopuszczalności. Jeżeli przyjąć, że na podstawie tego przepisu (a mówiąc ściślej, na podstawie normy wynikającej z tego przepisu) dopuszczalne jest oparcie skargi nadzwyczajnej zarówno na zarzucie dotyczącym ustaleń faktycznych, jak i zarzucie dotyczącym oceny dowodów, to w przypadku wykazania takiej podstawy przez podmiot uprawniony w skardze nadzwyczajnej powinna ona zostać rozpatrzona niezależnie od tego, czy podmiot powoła się na art. 89 § 1 pkt 2, czy też na pkt 3 ustawy o SN. Nie zmienia to oczywiście faktu, że skarga kasacyjna powinna zostać przygotowana w sposób profesjonalny, z zachowaniem najwyższego standardu staranności.

${ }^{97} \mathrm{Na}$ przykład brak wszechstronnego rozważenia całego materiału dowodowego; bezzasadna odmowa dopuszczenia dowodu naruszająca przepisy k.p.c.; ocena zebranego materiału dowodowego przeprowadzona z rażącym naruszeniem zasad logicznego rozumowania i w sposób oczywiście wadliwy.

${ }^{98}$ Wyrok SN z 5 IX 2002 r., sygn. II CKN 916/00, Legalis nr 59487.

${ }^{99}$ Zgodnie z art. $398^{13}$ \& 2 k.p.c. „W postępowaniu kasacyjnym nie jest dopuszczalne powołanie nowych faktów i dowodów, a Sąd Najwyższy jest związany ustaleniami faktycznymi stanowiącymi podstawę zaskarżonego orzeczenia".

${ }^{100}$ R.M. Bełczącki, Rozpoznanie skargi nadzwyczajnej...

${ }^{101}$ Może to sugerować, że przedmiotem analizy SN są tylko fakty i dowody, które znalazły się w aktach sprawy przed wniesieniem skargi nadzwyczajnej - ustalanie nowych faktów czy też przeprowadzanie nowych dowodów byłoby więc niedopuszczalne. 
nadzwyczajna może zostać oparta na zarzucie sprzeczności ustaleń sądu z treścią zebranego w sprawie materiału dowodowego, sprawa nie jest oczywista. Należy bowiem pamiętać, że w takim wypadku SN przestaje być związany ustaleniami faktycznymi stanowiącymi podstawę zaskarżonego orzeczenia ${ }^{102}$. W kontekście podnoszonych zarzutów w konkretnych okolicznościach powołanie nowych faktów lub dowodów może się więc okazać pożądane, a nawet niezbędne. Stąd nie należałoby a priori wykluczać takiej możliwości, zwłaszcza w sytuacji, w której podstawą skargi nadzwyczajnej będą zarzuty dotyczące ustalenia faktów lub oceny dowodów (w szczególności, gdy podstawę skargi stanowić będzie art. $89 \S 1$ pkt 3 ustawy o SN).

\subsection{Zaskarżenie prawomocnego orzeczenia sądu powszechnego lub sądu wojskowego kończącego postępowanie w sprawie}

Artykuł 89 \& 1 ustawy o SN przewiduje dwie kolejne obligatoryjne przesłanki dopuszczalności skargi nadzwyczajnej. Po pierwsze, skargą taką można zaskarżyć tylko i wyłącznie prawomocne orzeczenie sądu powszechnego lub sądu wojskowego kończącego postępowanie w sprawie. Po drugie, orzeczenie takie nie może być uchylone lub zmienione w trybie innych nadzwyczajnych środków zaskarżenia. Obie przesłanki zostaną kolejno omówione.

Pod pojęciem "prawomocnego orzeczenia kończącego sprawę" należy rozumieć zarówno wyroki, jak i postanowienia. Brak odpowiedniego substratu zaskarżenia oznacza niedopuszczalność skargi nadzwyczajnej, co wiąże się z koniecznością jej odrzucenia bez wzywania do usunięcia braków ${ }^{103}$. Co istotne, w przeciwieństwie do art. $398^{1} \S 1$ k.p.c., art. 89 $\S 1$ ustawy o SN nie odnosi się wyłącznie do wyroków (orzeczeń) sądu

102 Oznacza to, że na podstawie art. 95 pkt 1 ustawy o SN do postępowania w sprawie skargi nadzwyczajnej nie znajdzie zastosowania art. $398^{13} \S 2$ in fine k.p.c. (gdyż w związku z treścią art. $89 \S 1$ pkt 3 ustawy o SN, Sąd Najwyższy przestaje być związany ustaleniami faktycznymi stanowiącymi podstawę zaskarżonego orzeczenia), który z kolei funkcjonalnie powiązany jest $\mathrm{z}$ art. $398^{13} \S 2$ in principio k.p.c. Może to przemawiać za przyjęciem, iż art. $398^{13} \S 2$ k.p.c. w ogóle (w całości) nie znajdzie zastosowania do postępowania w sprawie skargi nadzwyczajnej.

103 Artykuł $89 \S 1$ ustawy o SN w zw. z art. $398^{6} \S 2$ lub 3 k.p.c. w zw. z art. 95 pkt 1 ustawy o SN. Tak samo R.M. Bełczącki, Badanie dopuszczalności skargi nadzwyczajnej przed Sądem Najwyższym ze względów podmiotowych i przedmiotowych w sprawie cywilnej. 
II instancji. Należy zatem przyjąć, że skarga nadzwyczajna może zostać wniesiona również w przypadku, w którym strona nie zaskarżyła orzeczenia sądu I instancji, które w związku z tym się uprawomocni$\nmid \mathrm{o}^{104}$. Dotychczas jedyny tego typu wyłom przewidziany był w art. $424^{1}$ $\S 2$ oraz art. $519^{2} \S 2$ k.p.c. na tle skargi o stwierdzenie niezgodności z prawem prawomocnego orzeczenia ${ }^{105}$. Ma on przy tym - inaczej niż w przypadku skargi nadzwyczajnej - charakter wyjątkowy. Wymóg, aby orzeczenie kończyło postępowanie w sprawie, oznacza z kolei, że wyłączona jest dopuszczalność wniesienia skargi nadzwyczajnej od wyroku II instancji uchylającego wyrok sądu I instancji i przekazującego sprawę do ponownego rozpoznania ${ }^{106}$. Istnieje natomiast możliwość zaskarżenia wyroków częściowych, końcowych, łącznych i uzupełniających ${ }^{107}$.

Pewne wątpliwości może natomiast budzić, czy skarga nadzwyczajna może zostać wniesiona od orzeczenia wydanego przez $\mathrm{SN}^{108}$. W art. 89 $\S 1$ ustawy o SN mowa jest bowiem o prawomocnym orzeczeniu sądu powszechnego. SN zaś sądem powszechnym nie jest ${ }^{109}$. Brak również

${ }^{104} \mathrm{~W}$ uzasadnieniu do projektu ustawy o SN wskazano, że "Skarga nadzwyczajna, inaczej niż skarga kasacyjna czy kasacja, będzie przysługiwała także od tych prawomocnych orzeczeń, od których nie złożono wcześniej odwołania" (uzasadnienie do projektu ustawy o SN, s. 6).

${ }^{105}$ Przepisy te przewiduja, że w wyjątkowych wypadkach, gdy niezgodność z prawem wynika $z$ naruszenia podstawowych zasad porządku prawnego lub konstytucyjnych wolności albo praw człowieka i obywatela, można także żądać stwierdzenia niezgodności z prawem prawomocnego wyroku (postanowienia co do istoty sprawy) sądu I lub II instancji kończącego postępowanie w sprawie, jeżeli strona nie skorzystała z przysługujących jej środków prawnych, chyba że jest możliwa zmiana lub uchylenie wyroku (postanowienia) w drodze innych przysługujących stronie środków prawnych.

106 Tak na tle skargi kasacyjnej: A. Zieliński, Komentarz do art. 3983. Warto wskazać, że podobną treść zawiera również art. $424^{1}$ k.p.c. TK orzekł, że art. $424^{1} \S 1$ i 2 k.p.c. w części obejmującej słowa "kończącego postępowanie w sprawie” jest niezgodny z art. 32 ust. 1 i art. 77 ust. 1 i 2 Konstytucji RP (wyrok TK z 1 IV 2008 r., sygn. SK 77/06, Legalis nr 95372). Powyższe oznacza, że przesłanką dopuszczalności skargi o stwierdzenie niezgodności z prawem prawomocnego orzeczenia jest jedynie prawomocność orzeczenia sądu II instancji. Wymóg, aby orzeczenie kończyło postępowanie w sprawie, w świetle orzeczenia TK przestał istnieć (A. Zieliński, Komentarz do art. 3983).

${ }^{107}$ Ibidem. Wątpliwości budzi natomiast, czy za wyrok kończący postępowanie może być uznany wyrok wstępny (wyrok SN z 16 IV 1997 r., sygn. II CKN 106/97, Legalis nr 30969).

${ }^{108}$ W doktrynie wskazuje się, że zaskarżenie skargą nadzwyczajną orzeczenia Sądu Najwyższego jest niedopuszczalne (R.M. Bełczącki, Badanie dopuszczalności skargi nadzwyczajnej przed Sądem Najwyższym ze względów podmiotowych i przedmiotowych w sprawie cywilnej. Autor nie odnosi się jednak do treści art. $89 \S 3 \mathrm{zd}$. 1 ustawy o SN).

${ }^{109}$ Zgodnie bowiem z art. 175 ust. 1 Konstytucji RP „Wymiar sprawiedliwości w Rzeczypospolitej Polskiej sprawują Sąd Najwyższy, sądy powszechne, sądy administracyjne oraz sądy wojskowe". 
przepisu, który określałby skład SN właściwy do rozpoznania skargi nadzwyczajnej od wyroku wydanego bezpośrednio przez $\mathrm{SN}^{110}$. Z drugiej strony w ustawie o SN brak jest również odpowiednika art. $424^{1 \mathrm{a}}$ § 1 k.p.c., który explicite przewidywałby zakaz zaskarżania orzeczeń SN. Niemniej treść art. $89 \S 1$ ustawy o SN przemawia za przyjęciem, że zaskarżenie skargą nadzwyczajną orzeczenia SN jest niedopuszczalne ${ }^{111}$.

Nie powinna natomiast budzić wątpliwości możliwość zaskarżenia prawomocnego orzeczenia sądu powszechnego wydanego w sprawie, w której na wcześniejszym etapie zapadło orzeczenie SN. Przykładowo, SN mógł uchylić zaskarżone orzeczenie sądu I lub II instancji w całości lub w części i przekazać sprawę do ponownego rozpoznania, w konsekwencji czego zapadło kolejne prawomocne orzeczenie sądu powszechnego. Brak więc przeszkód, aby takie orzeczenie zaskarżone zostało skargą nadzwyczajną ${ }^{112}$. Możliwe będzie również zaskarżenie prawomocnego orzeczenia, od którego co prawda skarga kasacyjna została wniesiona, lecz którą SN oddalił113. Skargi nadzwyczajnej nie można jednak oprzeć na zarzutach, które były przedmiotem rozpoznawania skargi kasacyjnej przyjętej do rozpoznania przez $\mathrm{SN}^{114}$. Teoretycznie nie da się również wykluczyć sytuacji, w której skarga nadzwyczajna wniesiona zostanie

${ }^{110}$ Artykuł 94 § 2 ustawy o SN określa jedynie skład SN właściwy do rozpatrzenia skargi nadzwyczajnej dotyczącej orzeczenia zapadłego w wyniku postępowania, w którego toku orzeczenie wydał $\mathrm{SN}$.

${ }^{111} \mathrm{~W}$ istocie chodzi o sytuację, w której SN uchyla zaskarżone orzeczenie (w całości lub w części) i orzeka co do istoty sprawy (art. $91 \S 1 \mathrm{zd}$. 1 ustawy o SN w przypadku skargi nadzwyczajnej i art. $398^{16}$ zd. 1 k.p.c. w przypadku skargi kasacyjnej), a także o orzeczenia wydane przez SN na podstawie art. $424^{11}$ k.p.c.

112 Oczywiście tylko wówczas, gdy nie będzie możliwości wniesienia skargi kasacyjnej lub innego nadzwyczajnego środka zaskarżenia.

${ }^{113}$ R.M. Bełczącki, Badanie dopuszczalności skargi nadzwyczajnej przed Sądem Najwyższym ze względów podmiotowych i przedmiotowych w sprawie cywilnej; idem, Badanie dopuszczalności skargi nadzwyczajnej przed Sądem Najwyższym ze względu na zachowanie terminu do jej wniesienia w sprawie cywilnej. Wówczas skarga nadzwyczajna będzie mogła zostać wniesiona w terminie roku od rozpoznania skargi kasacyjnej (art. 89 § $3 \mathrm{zd}$. 1 ustawy o SN). Pytanie, czy roczny termin odnosi się również do sytuacji, w której skarga kasacyjna została odrzucona lub której SN nie przyjął do rozpoznania. Stricte rzecz ujmując, w obu wypadkach nie następuje rozpoznanie skargi kasacyjnej, w związku z czym wydaje się, że zastosowanie znajdzie termin pięcioletni liczony od dnia uprawomocnienia się wyroku sądu powszechnego (art. $89 \S 3$ zd. 1 ustawy o SN).

114 Skarga nadzwyczajna wniesiona wyłącznie na takich podstawach zostanie odrzucona (art. $90 \S 2$ w zw. z art. $398^{6} \S 2$ lub 3 w zw. z art. 95 ustawy o SN). Natomiast jeżeli zostanie oparta zarówno na podstawach dopuszczalnych, jak i tych niedopuszczalnych, te ostatnie zostaną pominięte. Wydaje się, że dyspozycją art. $90 § 2$ ustawy o SN nie jest 
w sprawie, w której na wcześniejszym etapie SN już raz rozpatrywał skargę nadzwyczajną i uwzględniając ja, na podstawie art. 91 § 1 ustawy o SN, uchylił zaskarżone orzeczenie w całości lub w części i przekazał sprawę do ponownego rozpoznania właściwemu sądowi. Brak podstaw, by uznać, że wydane w następstwie tego prawomocne orzeczenie sądu powszechnego nie może zostać zaskarżone skargą nadzwyczajną ${ }^{115}$. Niemniej wystąpienie takiej sytuacji w praktyce wydaje się mało prawdopodobne ${ }^{116}$.

Natomiast w odniesieniu do postanowień kończących postępowanie w sprawie art. $89 \S 1$ ustawy o SN nie zawiera ograniczenia analogicznego do tego, które przewidziane zostało w art. $398^{1} \S 1$ k.p.c. W przeciwieństwie zatem do skargi kasacyjnej skarga nadzwyczajna może zostać wniesiona nie tylko od postanowień w przedmiocie odrzucenia pozwu albo umorzenia postępowania, ale również od innych prawomocnych postanowień kończących postępowanie w sprawie. Chodzi o postanowienia co do istoty sprawy kończące postępowanie nieprocesowe ${ }^{117}$. Skargą nadzwyczajną nie można natomiast zaskarżyć zarządzeń przewodniczącego ${ }^{118}$.

\subsection{Brak możliwości uchylenia lub zmiany prawomocnego orzeczenia w trybie innych nadzwyczajnych środków zaskarżenia}

Ustawa o SN ani k.p.c. ${ }^{119}$ nie określają, co należy rozumieć przez nadzwyczajny środek zaskarżenia, niemniej w nauce do nadzwyczajnych

objęty przedmiot wniosku o przyjęcie skargi kasacyjnej do rozpoznania, nie stanowi bowiem podstawy jej wniesienia.

115 Oczywiście pod warunkiem, że brak jest możliwości wniesienia w sprawie skargi kasacyjnej lub innego nadzwyczajnego środka zaskarżenia.

${ }^{116}$ Zdaje się, że taka sytuacja nie została objęta dyspozycją art. $90 \S 1$ ustawy o SN. Zgodnie z tym przepisem "Od tego samego orzeczenia w interesie tej samej strony skarga nadzwyczajna może być wniesiona tylko raz". Tymczasem przedmiotem zaskarżenia kolejną skargą nadzwyczajną byłoby inne orzeczenie. Niezależnie od tego należy pamiętać, że nie można oprzeć skargi nadzwyczajnej od orzeczenia wydanego po ponownym rozpoznaniu sprawy na podstawach sprzecznych z wykładnią prawa dokonaną w tej sprawie przez SN (art. $398^{20}$ zd. 2 k.p.c. w zw. z art. 95 pkt 1 ustawy o SN).

117 R.M. Bełczącki, Badanie dopuszczalności skargi nadzwyczajnej przed Sądem Najwyższym ze względów podmiotowych i przedmiotowych w sprawie cywilnej.

${ }^{118}$ Ibidem; idem, Wniesienie skargi nadzwyczajnej...

${ }^{119}$ W k.p.c. mowa jest jedynie o środkach odwoławczych (Część pierwsza. Postępowanie rozpoznawcze, Księga pierwsza. Proces, Tytuł VI. Postępowanie, Dział V. Środki odwoławcze k.p.c.). 
środków zaskarżenia zalicza się skargę kasacyjną ${ }^{120}$, skargę o wznowienie postępowania ${ }^{121}$ oraz skargę o stwierdzenie niezgodności z prawem prawomocnego orzeczenia ${ }^{122}$. Obecnie należałoby uznać, że do takich środków zalicza się również skargę nadzwyczajną.

Zbliżony do art. $89 \S 1$ in fine ustawy o SN charakter ma art. $424^{1} \S 1$ k.p.c., zgodnie z którym wniesienie skargi o stwierdzenie niezgodności z prawem prawomocnego orzeczenia jest możliwe tylko wówczas, gdy zmiana lub uchylenie tego wyroku $\mathrm{w}$ drodze przysługujących stronie środków prawnych nie było i nie jest możliwe ${ }^{123}$. Jednak po pierwsze, $\mathrm{w}$ przepisie tym mowa jest o środkach prawnych (a nie środkach zaskarżenia) ${ }^{124}$, a po drugie, brak jest wymogu, aby miały one charakter

${ }^{120}$ H. Pietrzkowski, Metodyka pracy sędziego w sprawach cywilnych, Warszawa 2012, wyd. 6, s. 591; idem, Czynności procesowe zawodowego petnomocnika w sprawach cywilnych, Warszawa 2010, s. 415.

${ }^{121}$ H. Pietrzkowski, Metodyka..., s. 615; H. Pietrzkowski, Czynności..., s. 449.

${ }^{122}$ H. Pietrzkowski, Metodyka..., s. 640; H. Pietrzkowski, Czynności..., s. 483.

${ }^{123}$ W wyroku SN z 13 IX 2012 r., sygn. IV CNP 34/12, Legalis nr 544721, sąd wskazał, że "Stosownie do treści art. $424^{5} \S 1$ pkt 5 k.p.c. skarga o stwierdzenie niezgodności z prawem prawomocnego wyroku powinna zawierać między innymi «wykazanie, że wzruszenie zaskarżonego orzeczenia $\mathrm{w}$ drodze innych środków prawnych nie było i nie jest możliwe». Takie ujęcie jednego z warunków konstrukcyjnych skargi oznacza obciążenie skarżącego obowiązkiem przedstawienia analizy prawnej przepisów dotyczących środków zaskarżenia, których zastosowanie - w odniesieniu do zaskarżonego orzeczenia - jest niedopuszczalne lub z innych przyczyn na pewno nie mogłoby odnieść skutku. Skarżący powinien zatem ujawnić i wykazać, w sposób wyczerpujący i niebudzący wątpliwości, w drodze stosownego wywodu, powołując odpowiednie przepisy, że od zaskarżonego wyroku nie przysługuje środek prawny, przy pomocy którego mogłoby nastąpić jego wzruszenie (zob. m.in. postanowienia Sądu Najwyższego z 17 VIII 2005 r., I CNP 5/05, OSNC 2006, nr 1, poz. 17; z 13 XII 2005 r., I CNP 28/05; z 27 I 2006 r., III CNP 23/05, OSNC 2006, nr 7-8, poz. 140; z 27 I 2006 r., III CNP 23/05, OSNC z 2006 r., nr 7-8, poz. 140; z 28 VI 2011 r., I CNP 16/11; z 22 VI 2012 r., V CNP 94/11)".

${ }^{124}$ Wydaje się, że środek prawny jest pojęciem szerszym od pojęcia środka zaskarżenia. Każdy środek zaskarżenia będzie środkiem prawnym, ale nie każdy środek prawny będzie środkiem zaskarżenia. W tym kontekście może się pojawić pytanie, co dzieje się w sytuacji, w której wniesienie nadzwyczajnego środka zaskarżenia nie będzie możliwe, natomiast strona mogłaby zwalczać negatywne skutki prawomocnego orzeczenia innymi środkami prawnymi. Przykładowo, strona (dłużnik) mogła utracić prawo do wytoczenia powództwa opozycyjnego ze względu na fakt wyegzekwowania świadczenia objętego tytułem wykonawczym, który może nie być wzruszalny nadzwyczajnymi środkami zaskarżenia. Niemniej nie oznacza to, że strona nie ma możliwości poszukiwania sądowej ochrony swoich praw w odrębnym postępowaniu (zob. wyrok SN z 20 I 1978 r., sygn. III CRN 310/77, Legalis nr 20637; wyrok SN z 17 XI 1988, sygn. I CR 255/88, Legalis nr 26473; wyrok SN z 4 IV 2002 r., sygn. I PKN 197/01, Legalis nr 55540). W takim wypadku raczej należałoby się opowiedzieć przeciwko możliwości wniesienia skargi nadzwyczajnej wobec braku gravamen, czy też interesu prawnego. 
nadzwyczajny. Zasadne wydaje się więc przyjęcie, że przez nadzwyczajne środki zaskarżenia w rozumieniu art. $89 \S 1$ in fine ustawy o SN należy rozmieć w szczególności skargę kasacyjną, skargę o wznowienie postępowania, skargę o stwierdzenie niezgodności z prawem prawomocnego orzeczenia wniesioną na podstawie art. $424^{11} \S 3$ k.p.c. ${ }^{125}$, a także zażalenia o których mowa w art. $394^{1} \S 1$ i 2 k.p.c. ${ }^{126}$ Taka wykładnia prowadzi również do systemowo logicznych wniosków. Wydaje się bowiem, że intencją ustawodawcy było, aby skarga nadzwyczajna mogła zostać wniesiona tylko wówczas, gdy prawomocne orzeczenie nie może zostać wzruszone w jakikolwiek inny sposób, a więc aby miała charakter subsydiarny ${ }^{127}$. W przypadku gdy istnieje możliwość uchylenia lub zmiany zaskarżonego orzeczenia innymi niż skarga nadzwyczajna środkami zaskarżenia, ta podlega odrzuceniu bez wzywania do usunięcia braków ${ }^{128}$.

Pewne wątpliwości może natomiast budzić sytuacja, w której możliwe będzie równoczesne wniesienie skargi o stwierdzenie niezgodności z prawem prawomocnego orzeczenia na podstawie art. $424^{11} \S 3$ k.p.c. oraz skargi nadzwyczajnej. W takim wypadku, formalnie rzecz ujmując, oba środki należałoby uznać za niedopuszczalne. $Z$ perspektywy art. $424^{1} \S 1$ k.p.c. możliwa byłaby zmiana lub uchylenie orzeczenia za pomocą skargi nadzwyczajnej. Natomiast z perspektywy art. $89 \S 1$ in fine ustawy o SN taką możliwość dawałaby skarga o stwierdzenie niezgodności z prawem prawomocnego orzeczenia wnoszona na podstawie art. $424^{11} \S 3$ k.p.c. Oba środki blokowałyby (wykluczałyby) się więc wzajemnie. Biorąc pod uwagę szczególnie wyjątkowy i subsydiarny charakter skargi nadzwyczajnej, zasadne wydaje się przyjęcie, że w takim wypadku w pierwszej kolejności na podstawie art. $424^{11} \S 3$ k.p.c. powinna zostać wniesiona skarga o stwierdzenie niezgodności z prawem prawomocnego orzeczenia, choć nie sposób wykluczyć odmiennej

${ }^{125}$ R.M. Bełczącki, Badanie dopuszczalności skargi nadzwyczajnej przed Sąem Najwyższym ze względów podmiotowych i przedmiotowych w sprawie cywilnej. Autor słusznie wskazuje, że w pozostałych wypadkach skarga o stwierdzenie niezgodności z prawem prawomocnego orzeczenia nie może prowadzić do zmiany lub uchylenia zaskarżonego orzeczenia.

${ }^{126}$ Zażalenie, o którym mowa w art. $394^{1} \S 1$ a k.p.c., ma specyficzny charakter i nie odnosi się do prawomocnego orzeczenia kończącego sprawę.

${ }^{127}$ R.M. Bełczącki, Badanie dopuszczalności skargi nadzwyczajnej przed Sadem Najwyższym ze względów podmiotowych i przedmiotowych w sprawie cywilnej.

${ }^{128}$ Artykuł $89 \S 1$ ustawy o SN w zw. z art. $398^{6} \S 2$ lub 3 k.p.c. w zw. z art. 95 pkt 1 ustawy o SN. 
interpretacji. W pozostałych sytuacjach skarga o stwierdzenie nieważności z prawem prawomocnego orzeczenia nie prowadzi do uchylenia lub zmiany takiego orzeczenia, w związku z czym jej wniesienie nie jest warunkiem koniecznym do wniesienia skargi nadzwyczajnej.

W tym kontekście pojawia się również pytanie, co dzieje się w przypadku, gdy strona miała możliwość podważania prawomocnego orzeczenia w trybie innych nadzwyczajnych środków zaskarżenia, lecz z niej nie skorzystała. Na tle podobnych wątpliwości wynikających z treści art. $424^{1} \S 1$ k.p.c. SN w postanowieniu z 29 I 2008 r., sygn. I BU 13/07, Legalis nr 114370, stwierdził podstawę do odrzucenia takiej skargi z mocy art. $424^{8} \S 2$ k.p.c., ponieważ zmiana zaskarżonego orzeczenia była możliwa na podstawie skargi kasacyjnej, lecz strona tego nie uczyniła. Podobnie w innym postanowieniu SN stwierdził, że na podstawie omawianej skargi postępowanie co do zasady (wyjątek wynika z art. $424^{1} \S 2$ oraz art. $519^{2} \S 2$ k.p.c.) wszczynane powinno być tylko wtedy, gdy strona wykorzystała wszystkie środki prawne, które mogłyby doprowadzić do zmiany lub uchylenia wyroku ${ }^{129}$. Takie stanowisko koresponduje zresztą z treścią art. $424^{1} \S 2$ oraz art. $519^{2} \S 2$ k.p.c., które wyjątkowo dopuszczają możliwość wniesienia skargi o stwierdzenie nieważności prawomocnego orzeczenia, nawet gdy strona wcześniej nie wykorzystała (mimo iż taką możliwość miała) przysługujących jej środków prawnych - rozumując a contrario, co do zasady niewykorzystanie przysługujących środków wyklucza możliwość wniesienia skargi. W tym kontekście należy jednak zwrócić uwagę, że w art. $424^{1} \S 1$ oraz art. $519^{2}$ $\S 1$ k.p.c. mowa jest o tym, iż zmiana lub uchylenie wyroku w drodze przysługujących stronie środków prawnych nie było i nie jest możliwe. Tymczasem w art. $89 \S 1$ in fine ustawy o SN mowa jest o tym, że warunkiem wniesienia skargi nadzwyczajnej jest to, że zaskarżane orzeczenie nie może być uchylone lub zmienione w trybie innych nadzwyczajnych środków zaskarżenia. $Z$ literalnego brzmienia tego przepisu wynika więc jedynie wymóg, aby w dniu wnoszenia skargi nadzwyczajnej uchylenie lub zmiana zaskarżanego orzeczenia nie była możliwa w trybie innych nadzwyczajnych środków zaskarżenia. Przyjęcie, że wniesienie skargi nadzwyczajnej jest możliwe mimo niewykorzystania przez stronę przysługującego lub przysługujących jej wcześniej nadzwyczajnych środków zaskarżenia, korespondowałoby z zasada, iż skarga nadzwyczajna może zostać wniesiona również w tych przypadkach, w których strona

${ }^{129}$ Postanowienie SN z 13 IX 2012 r., sygn. IV CNP 34/12, Legalis nr 544721. 
nie zaskarżyła orzeczenia sądu I instancji, a które w związku z tym się uprawomocniło ${ }^{130}$. Taka wykładnia w szerszym zakresie realizowałaby więc prawo obywatela do sądu. Pojawia się jednak pytanie, czy przepisy powinny w tak dalekim stopniu chronić prawa i interesy strony, która zwłaszcza gdy czyni to świadomie - sama rezygnuje z przysługujących jej w tym zakresie uprawnień. Warto też pamiętać, że prawomocność orzeczeń, zapewniająca stabilność i bezpieczeństwo obrotu, stanowi istotną wartość samą w sobie.

\section{Wniesienie i rozpatrzenie skargi nadzwyczajnej}

Zgodnie z art. 95 pkt 1 ustawy o SN, w zakresie nieuregulowanym przepisami tej ustawy, do skargi nadzwyczajnej, w tym do postępowania w sprawie tej skargi, stosuje się w zakresie spraw cywilnych przepisy k.p.c. dotyczące skargi kasacyjnej, z wyłączeniem jednak art. $398^{4} \S 2$ oraz art. $398^{9}$ k.p.c. (regulacje dotyczące przedsądu). Natomiast zgodnie $\mathrm{z}$ art. $398^{21}$ (in principio) k.p.c., jeżeli nie ma szczególnych przepisów o postępowaniu przed SN, do postępowania tego stosuje się odpowiednio przepisy o apelacji ${ }^{131}$. Oznacza to, że w zakresie nieuregulowanym przepisami ustawy o SN oraz przepisami k.p.c. o skardze kasacyjnej ${ }^{132}$, do postępowania przed SN w sprawie skargi nadzwyczajnej odpowiednie zastosowanie znajdą również przepisy k.p.c. o apelacji ${ }^{133}$. Odpowiednie stosowanie tych przepisów powinno przy tym uwzględniać, że postępowanie zainicjowane skargą nadzwyczajną toczy się już po wydaniu prawomocnego orzeczenia, a także specyfikę tego postępowania $^{134}$.

W tym kontekście wątpliwości budzi, czy skargę nadzwyczajną należy wnieść bezpośrednio do SN czy też do sądu, który wydał zaskarżane orzeczenie. W doktrynie opowiedziano się za pierwszym stanowiskiem, uzasadniając to m.in. faktem, że rewizja nadzwyczajna

${ }^{130}$ Zob. przypis $104 \mathrm{w}$ niniejszym tekście.

131 Artykuły 367-391 k.p.c.

132 Artykuły $398^{1}-398^{21}$ k.p.c.

${ }^{133}$ Termin na sporządzenie uzasadnienia orzeczenia przez SN wynosi miesiąc (art. $398^{21}$ in fine k.p.c. w zw. $z$ art. 95 pkt 1 ustawy o SN). Pojawia się natomiast pytanie, czy skargę nadzwyczajną może cofnąć sama strona (art. $398^{21}$ k.p.c. w zw. z art. 95 pkt 1 ustawy o SN).

${ }^{134}$ Podobnie na tle skargi kasacyjnej M. Manowska, Komentarz do art. $398^{21}$, w: Kodeks postepowania cywilnego Komentarz, pod red. M. Manowskiej, Warszawa 2013. 
również wnoszona była bezpośrednio do $\mathrm{SN}^{135}$. W istocie jednak brak jest normatywnych podstaw, aby w świetle treści art. 95 pkt 1 ustawy o SN do postępowania w sprawie skargi nadzwyczajnej nie stosować art. $398^{5}$ \& 1 k.p.c. ${ }^{136}$ Wszak ustawa o SN nie zawiera szczegółowej regulacji w tym zakresie. W szczególności brak jest przepisu, który wskazywałby, że skargę nadzwyczajną należy wnieść bezpośrednio do SN. Odwołując się zaś do przepisów regulujących postępowanie w sprawie skargi kasacyjnej, należałoby przyjąć, że skargę nadzwyczajną należy wnieść do sądu, który wydał zaskarżane orzeczenie ${ }^{137}$.

W przypadku uwzględnienia skargi nadzwyczajnej, SN uchyla zaskarżone orzeczenie w całości lub w części i stosownie do wyników postępowania orzeka co do istoty sprawy albo przekazuje sprawę do ponownego rozpoznania właściwemu sądowi, w razie potrzeby uchylając także orzeczenie sądu I instancji, albo umarza postępowanie ${ }^{138}$. W doktrynie wskazano, że w tym zakresie na podstawie art. 95 pkt 1 ustawy o SN zastosowanie znajdzie art. $398^{16}$ zd. 1 k.p.c. ${ }^{139}$, który uzależnia możliwość orzeczenia co do istoty sprawy m.in. od oczywistej zasadności naruszenia prawa materialnego oraz od wniosku strony. Wydaje się jednak, że kwestia ta uregulowana została autonomicznie w art. $91 \S 1$ zd. 1 ustawy o SN, w związku z czym brak jest podstaw, by w tym zakresie stosować - choćby odpowiednio - art. $398^{16}$ zd. 1 k.p.c. Artykuł 95 pkt 1 ustawy o SN każe bowiem stosować przepisy k.p.c. jedynie w zakresie nieuregulowanym przepisami ustawy o SN. Należy zatem przyjąć, że uchylając zaskarżone orzeczenie i orzekając co do istoty sprawy, SN nie jest związany dyspozycją art. $398^{16}$ zd. 1 k.p.c. i może w ten sposób postąpić nawet wówczas, gdy naruszenie prawa nie jest oczywiście zasadne lub gdy skarżący nie złożył wniosku w tym

${ }^{135}$ R.M. Bełczącki, Wniesienie skargi nadzwyczajnej...

${ }^{136}$ Zgodnie z tym przepisem "Skargę kasacyjną wnosi się do sądu, który wydał zaskarżone orzeczenie, w terminie dwóch miesięcy od dnia doręczenia orzeczenia z uzasadnieniem stronie skarżącej".

${ }^{137}$ Artykuł $398^{5} \S 1$ k.p.c. w zw. z art. 95 pkt 1 ustawy o SN.

138 Artykuł $91 \S 1$ zd. 1 ustawy o SN. Tym samym na podstawie art. 95 pkt 1 ustawy o SN do skargi nadzwyczajnej nie znajdzie zastosowania art. $398^{15} \S 1$ zd. 1 k.p.c. Zastosowanie znajdzie jednak na podstawie art. 95 pkt 1 ustawy o SN, art. $398^{15} \S 1$ zd. 2 (a tym samym art. 415 k.p.c.) oraz art. $398^{15} \S 2$ k.p.c. W razie przekazania sprawy do ponownego rozpoznania sąd rozpoznaje ją w innym składzie (art. $398^{15} \S 2$ k.p.c. w zw. z art. 95 pkt 1 ustawy o SN). Sąd, któremu sprawa została przekazana, związany jest wykładnią prawa dokonaną w tej sprawie przez SN (art. $398^{20}$ zd. 1 k.p.c. w zw. z art. 95 pkt 1 ustawy o SN).

${ }^{139}$ R.M. Bełczącki, Wniesienie skargi nadzwyczajnej... 
przedmiocie. Co więcej, warto rozważyć dopuszczalność uchylenia wyroku i orzeczenia przez SN co do istoty sprawy również wówczas, gdy skargę nadzwyczajną oparto także na podstawie naruszenia przepisów postępowania i podstawa ta okazała się uzasadniona, pod warunkiem że wynik postępowania by na to pozwalał. Jeżeli pozew ulegał odrzuceniu albo istniała podstawa do umorzenia postępowania, SN uchyla wydane $\mathrm{w}$ sprawie wyroki oraz odrzuca pozew lub umarza postępowanie ${ }^{140}$.

SN oddala skargę nadzwyczajna, jeżeli stwierdzi brak podstawy do uchylenia zaskarżonego orzeczenia ${ }^{141}$. Wątpliwości budzi natomiast, czy SN może oddalić skargę, jeżeli zaskarżone orzeczenie mimo błędnego uzasadnienia odpowiada prawu. W ustawie o SN brak jest bowiem odpowiednika art. $398^{14}$ in fine k.p.c.

Pewne wątpliwości budzi natomiast treść art. $89 \S 4$ ustawy o SN ${ }^{142}$. Przepis ten przewiduje, że nawet w przypadku, w którym skarga nadzwyczajna miałaby się okazać zasadna, ale zaskarżone orzeczenie wywołało nieodwracalne skutki prawne, w szczególności jeżeli od dnia uprawomocnienia się zaskarżonego orzeczenia upłynęło 5 lat, a także jeżeli uchylenie orzeczenia naruszyłoby międzynarodowe zobowiązania Rzeczypospolitej Polskiej, SN ogranicza się do stwierdzenia wydania zaskarżonego orzeczenia $\mathrm{z}$ naruszeniem prawa oraz wskazania okoliczności, z powodu których wydał takie rozstrzygnięcie. SN może jednak zastosować art. $91 \S 1$ ustawy o SN, jeżeli zasady lub wolności i prawa człowieka i obywatela określone w Konstytucji RP przemawiają za wydaniem rozstrzygnięcia uchylającego orzeczenie. Wątpliwości pojawiają się $w$ dwóch płaszczyznach. Po pierwsze, z literalnego brzmienia tego przepisu wynika, że upływ 5 lat od dnia uprawomocnienia się zaskarżonego orzeczenia w istocie należy kwalifikować jako wywołanie nieodwracalnych skutków prawnych, podczas gdy nie zawsze tak będzie. W takich wypadkach SN co do zasady nie mógłby więc stosować art. 91 $\S 1$ ustawy o SN, chyba że spełniona zostałaby przesłanka z art. $89 \S 4$

${ }^{140}$ Artykuł $398^{19}$ zd. 1 k.p.c. w zw. z art. 95 pkt 1 ustawy o SN. W takim wypadku przepis art. 415 k.p.c. stosuje się odpowiednio (art. $398^{19}$ zd. 2 k.p.c. w zw. z art. 95 pkt 1 ustawy o SN).

${ }^{141}$ Artykuł $91 \S 1$ zd. 2 ustawy o SN.

${ }^{142}$ Aktualna treść przepisu wprowadzona na mocy art. 2 pkt 3 lit. b nowelizacji ustawy o SN. Zbliżony charakter ma aktualna treść art. 115 \& ustawy o SN (wprowadzona na mocy art. 2 pkt 5 lit. b nowelizacji ustawy o SN), który odnosi się do skarg nadzwyczajnych wnoszonych od prawomocnych orzeczeń kończących postępowanie w sprawach, które uprawomocnily się po dniu 17 X 1997 r., a przed dniem 3 IV 2018 r. (art. $115 \S 1$ ustawy o SN). 
in fine ustawy o SN. Taka wykładnia podważałaby jednak co do zasady sens wnoszenia skarg nadzwyczajnych w odniesieniu do takich orzeczeń (art. 115 ustawy o SN). Po drugie, przesłanka umożliwiająca uchylenie zaskarżonego orzeczenia i orzeknięcie przez SN co do istoty sprawy lub przekazanie sprawy do ponownego rozpoznania (a więc umożliwiająca zastosowanie art. 91 § 1 ustawy o SN) stanowi kolejną klauzulę porządku publicznego $\mathrm{w}$ istocie pokrywającą się z podstawą główną skargi nadzwyczajnej i podstawą fakultatywną z art. 89 § 1 pkt 1 ustawy o SN. Prowadzi to do wniosku, że z założenia w sprawach, w których wniesienie skargi nadzwyczajnej okaże się zasadne, w istocie pożądane będzie również uchylenie zaskarżonego orzeczenia, nawet jeżeli upłynęło 5 lat od dnia uprawomocnienia się zaskarżonego orzeczenia (art. $91 \S 1$ zd. 1 ustawy o SN). Artykuł $89 \S 4$ oraz art. 115 § 2 ustawy o SN nie są więc w pełni spójne i logiczne.

\section{Podsumowanie}

Istotą wprowadzenia nowego środka zaskarżenia, jakim jest skarga nadzwyczajna, było uwypuklenie konieczności respektowania przez sądy, przy orzekaniu, zasad konstytucyjnych oraz chronionych konstytucyjnie wolności i praw człowieka i obywatela. Obecnie wszystkie podmioty uprawnione mogą wnosić skargi nadzwyczajne - z zastrzeżeniem, że podmioty inne niż PG i RPO mogą to czynić jedynie w zakresie swojej właściwości - od orzeczeń, które się uprawomocniły po dniu 3 kwietnia 2018 r. (włącznie) ${ }^{143}$. PG i RPO mogą ponadto do dnia 3 kwietnia 2021 r. wnosić skargi nadzwyczajne od prawomocnych orzeczeń kończących postępowanie w sprawach, które uprawomocniły się po dniu 17 października 1997 r. (a przed wejściem w życie ustawy o SN) ${ }^{144}$. Instytucja ta stwarza więc szansę na wzruszanie i odwracanie skutków tych orzeczeń, które chociaż nie mogą być podważone w żaden inny sposób, rażąco naruszają prawo i wyrządzają stronie wymierną szkodę lub krzywdę, stojąc przy tym w sprzeczności z elementarnym poczuciem sprawiedliwości. Równocześnie bardzo szerokie ujęcie podstaw skargi nadzwyczajnej pozostawia organom uprawnionym niezwykle dużą swobodę w przedmiocie wniesienia skargi, Sądowi Najwyższemu zaś

${ }^{143}$ Artykuł 89 § 2 w zw. z art. 136 ustawy o SN; art. $115 \S 1$ i 1 a ustawy o SN - argumentacja a contrario.

${ }^{144}$ Artykuł 115 \& 1 i 1 a ustawy o SN. 
takąż swobodę w przedmiocie oceny jej zasadności. W efekcie trudno przewidzieć, w jaki sposób kształtować się będzie orzecznictwo SN $\mathrm{w}$ tym zakresie.

\section{THE EXTRAORDINARY COMPLAINT IN THE CIVIL PROCEDURE - SELECTED ISSUES}

\section{Sum mary}

On the $3^{\text {rd }}$ April 2018, a new Act of the $8^{\text {th }}$ December 2017 regarding the Supreme Court (Journal of Laws 2018 item 5 as amended), hereinafter the "Law regarding the Supreme Court", entered into force, which introduced to the polish legal system a new institution, namely the extraordinary complaint. It is a new remedy, the purpose of which is the extraordinary review of final court decisions (judgements) in order to ensure their compliance with the principle of a democratic state of law that implements the principles of social justice. It may be brought before the Supreme Court only by certain public authorities strictly specified in the Law regarding the Supreme Court, namely by the Attorney General and the Ombudsman but also, within the scope of their jurisdiction, inter alia by the Financial Ombudsman, the Small and Medium-sized Enterprises Ombudsman and the President of the Office for Competition and Consumer Protection. Thus, these entities were given the right to challenge final judgments of common courts, which otherwise could not be revoked or changed by any other means or remedies. Currently, all legitimized authorities may file extraordinary complaints - with the reservation that authorities other than the Attorney General and the Ombudsman may do so only within their jurisdiction - regarding judgments that became final after the $3^{\text {rd }}$ April 2018 (inclusive). However, the Attorney General and the Ombudsman may also, until the $3^{\text {rd }}$ April 2021, file extraordinary complaints regarding judgments that became final after the $17^{\text {th }}$ October 1997 and before the $3^{\text {rd }}$ April 2018 (the date the Law regarding the Supreme Court entered into force).

Aim of the article is to analyze the main legal issues regarding the extraordinary complaint, especially the grounds for its admissibility, the practical aspects in the subject matter, as well as possible disputable issues and interpretation doubts. The study is limited to the analysis of selected legal issues regarding the extraordinary complaint in the civil procedure.

Keywords: extraordinary complaint - civil procedure - Supreme Court - cassation complaint 